Review

\title{
Nitric Oxide and Cancer Development
}

\author{
Robert A. Floyd ${ }^{1,2}$, Yashige Kotake ${ }^{1}$, Rheal A. Towner ${ }^{1}$, We-Xing Guo ${ }^{1}$, \\ Dai Nakae ${ }^{3,4}$, and Yoichi Konishi ${ }^{5}$ \\ ${ }_{1}^{1}$ Oklahoma Medical Research Foundation, 825 NE 13th Street, Oklahoma City, OK 73104, USA \\ ${ }^{2}$ Department of Biochemistry and Molecular Biology, University of Oklahoma Health Sciences Center, Oklahoma City, \\ OK 73104, USA \\ 3 Tokyo Metropolitan Institute of Public Health, 3-24-1 Hyakunincho, Shinjuku, Tokyo 169-0073, Japan \\ ${ }^{4}$ Tokyo University of Agriculture, 1-1-1 Sakuragaoka, Setagaya, Tokyo 156-8502, Japan \\ 5 International Federation of Societies of Toxicologic Pathologists, Yamamoto Green Village 2-303, \\ 2-34 Nakamozu-cho, Kita-ku, Sakai, Osaka 591-8023, Japan
}

\begin{abstract}
The role of nitric oxide (NO) in cancer development has become a very active research area. This review presents an overview of many studies that implicate an important role of NO in the development of cancer. These include results in experimental models as well as many observations made on NO and inducible nitric oxide synthase (iNOS) in human cancers. Our survey of the literature has allowed us to conclude that in general large levels of NO will kill cancer cells but paradoxically at intermediate to lower levels NO prevents cancer cell apoptosis and enhances tumor growth. This basic tenet has been demonstrated in many experimental models. The mechanistic basis of how intermediate levels of NO mediate tumor development is an active area of research and is the subject of this review. NO mediated S-nitrosylation of key enzymes and regulatory proteins plays a critical role. Key proteins S-nitrosylated which enhance tumor development include several caspases involved in apoptosis, PTEN the tumor suppressor protein, Bcl-2 the mitochondrial protein which protects from apoptosis, OGG1 the DNA repair protein and methionine adenosyl transferase the liver protein which synthesizes adenosylmethionine. The S-nitrosylation of these proteins enhances DNA mutations, prevents cancer cell apoptosis and enhances oncogenic cell growth. (J Toxicol Pathol 2007; 20: 77-92)
\end{abstract}

Key words: nitric oxide, nitric oxide synthase, protein S-nitrosylation, nitrones, cancer, phenyl-tert-butyl-nitrone

\section{Introduction and Overview}

Since the discovery in 1987 that nitric oxide was equivalent to endothelial relaxing factor (EDRF), this gaseous free radical as well as its reaction products (peroxynitrite, nitronium ion, $\mathrm{N}_{2} \mathrm{O}_{3}$ and others) have been shown to be important in many biological processes in addition to the control of blood pressure. Nearly simultaneous with the discovery that NO was EDRF, independently Hibbs and coworkers showed that NO was the active factor in the macrophage mediated killing of tumor cells in model systems ${ }^{1}$. Research in the area of NO mediated killing of tumor cells by macrophages has continued since the early observations, and as anticipated, observations since then have demonstrated that the processes and cell biology involved is more complex than originally conceived $^{2}$. This area will not be covered in this review.

Received: 30 March 2007, Accepted: 5 April 2007

Mailing address: Robert A. Floyd, Oklahoma Medical Research

Foundation, 825 NE 13th Street, Oklahoma City, OK 73104, USA

TEL: 1-405-271-7580 FAX: 1-405-271-1795

E-mail: robert-floyd@omrf.ouhsc.edu
Many observations over the last several years clearly implicate an important role for nitric oxide (NO) in the development of many human cancers as well as experimental models. Despite these observations it must be recognized that the role of NO in cancer development is a controversial area of research. This appears to be due to many reasons including the fact that $\mathrm{NO}$ is an important signaling molecule and has the capacity to alter many cellular processes depending upon its rate of production. In general, at very high levels of NO, cancer cell killing occurs and at very low levels there seems to be very little effect, however at more intermediate levels the results clearly indicate that NO protects cancer cells from apoptosis. Therefore NO has been shown to be both pro-apoptotic or anti-apoptotic depending upon many factors, including not only the flux and dose of NO, but on the specific cells involved, as well as on the redox state of these cells. The molecular mechanism as to how NO enhances cancer development has become an active area of research. In this review we will provide a survey of many observations in the literature. Our goal is to help synthesize a coherent view of the possible molecular processes involved on the role of NO in mediating cancer development. We present a rationale 
based on the literature along with a brief summary of some of our primary observations in an experimental hepatocellular carcinoma model. The rationale implicates NO mediated S-nitrosylation of critical cysteines in specific proteins play a major role in cancer development. This review presents the historical observations summarizing the discovery of NO in cancer cell killing. We then summarize some of the most important observations both in humans as well as experimental animal models demonstrating the importance of NO in cancer development. We then summarize NO reactions that may be the basis of why NO enhances cancer development. Finally we present some of the observations we have made that supports the notion that NO plays an important role in cancer development.

\section{Historical Observations}

The discovery that NO was the toxic agent produced by macrophages in their killing of tumor cells was made by Hibbs and colleagues in $1988^{1}$. This conclusion was the result of over an eight year span of research before nailing down the definitive identity of NO. Hibbs and colleagues demonstrated several important facts; A) that macrophagemediated killing of tumor cells was dependent on Larginine $\left.{ }^{3}, \mathrm{~B}\right)$ that L-arginine was metabolized to L-citrulline in the process, and that one of the guanidino nitrogens of arginine was oxidized to produce nitrite ${ }^{4}$. They also demonstrated C) that macrophages mediated the loss of aconitase activity ${ }^{5}$, caused the depletion of $\mathrm{Fe}^{6}$, and mediated the inhibition of mitochondrial respiration in tumor cells ${ }^{7}$. The occurrence of this research effort is remarkably near the same time (from early 1980 up to late 1987) that extensive research activity was also occurring independently by many groups especially those led by Ignarro, Moncada and Furchgott that led to the discovery that EDRF was equivalent to $\mathrm{NO}^{8-10}$. Paradoxically it was Moncada who had devoted much effort to the elucidation that NO was equivalent to EDRF, then later on, first definitely showed that NO generated from iNOS within cancer cells mediated the enhanced development of cancer in an experimental model $^{11}$.

\section{Studies Demonstrating Importance of iNOS and NO in Cancer}

Many observations on human subjects having various cancers have demonstrated that high levels of iNOS and NO are present in the tumors per se. In general a positive correlation of tumor aggressiveness with enhanced levels of iNOS/NO has been demonstrated for several different tumors. Many cancers have been studied with generally similar conclusions, see the review by Kirk et al. ${ }^{12}$. In fact Kirk et al. ${ }^{12}$ strongly suggest that therapeutic intervention of iNOS would impede tumor progression. A brief summary of the observations on liver cancer, prostate cancer, melanoma, colon cancer, gastric cancer, esophageal cancer and pancreatic cancers are presented here.
The subject of iNOS and liver tumor has not been studied as much as other tumors, however one recent study of 100 different HCC patients demonstrated that high expression of iNOS and COX-2 was correlated strongly with decreased length of patient survival ${ }^{13}$. It should be noted that surgerical resection is the treatment of choice for patients having $\mathrm{HCC}$ but $80 \%$ of these patients will have regrowth of their tumor in 2 years ${ }^{14}$. Regarding prostate cancer there are about 230,000 new cases diagnosed each year and about 30,000 deaths per year from it occur in the US ${ }^{15}$. It has been established in several studies that the intensity of iNOS expression in the target tissue of subjects is correlated with the severity of prostate tumor development ${ }^{16-20}$ and that it also has prognostic value ${ }^{19}$. The general relevant observations made in this field has lead to the belief that iNOS expression and NO formation generally contributes to tumor angiogenesis, tumor growth and metastasis, and tumor-related immune suppression ${ }^{17}$. A study with prostate tumor spheroids did show that enhanced NO formation was associated with a decrease in tumor cell death ${ }^{21}$. Concerning melanomas where 34,000 new cases are diagnosed annually ${ }^{22}$, several studies indicate that iNOS mediated-NO synthesis in melanoma cells is important in preventing their apoptosis ${ }^{22-24}$. One study of 52 primary malignant melanomas of the skin showed that iNOS was most frequently expressed in the "pure and invasive" radical growth phase, whereas in the vertical growth phase and metastatic phase it was less prevalently expressed ${ }^{25,26}$. They concluded that NO played an important part in the vertical growth phase of metastatic melanoma ${ }^{27}$. These general conclusions are supported by two other studies ${ }^{28,29}$.

In the case of colon cancer the American Cancer Society estimates that about 147,000 new colorectal cancers were diagnosed in 2004, with about 57,000 deaths that resulted from them ${ }^{15}$. There is a large amount of evidence showing that both iNOS and COX-2 are very important in the development of colon cancer ${ }^{30-40}$. Many studies have indicated a direct linkage of iNOS with the induction of COX-2 in colon cancer $33,37,38,40,41$. In the case of gastric cancer there are about 23,000 new cases of stomach cancer diagnosed per year ${ }^{15}$. The presence of iNOS in the target tissue of patients with gastric cancer has been known for some time ${ }^{42-46}$. Another major factor highly associated with gastric cancers is Helicobacter pylori infection ${ }^{47}$. There are higher levels of iNOS expression and higher levels of nitrotyrosine staining in gastric mucosa of subjects infected with $\mathrm{H}$. pylori ${ }^{42}$. Studies have shown that a specific $\mathrm{C}>\mathrm{T}$ polymorphism in exon 16 of iNOS is related to higher incidences of gastric cancer ${ }^{44,48-50}$. Transgenic mouse studies have shown that gastric mutation frequency is increased 4-fold in the mice infected with $\mathrm{H}$. pylori ${ }^{51}$. H. pylori infection is known to increase iNOS expression ${ }^{52}$. It is likely that increased NO production may lead to DNA damage. Oxidative damage to DNA as well as iNOS expression and cellular apoptosis has been shown to increase in those subjects infected with H. pylori ${ }^{53-55}$. The inability to express iNOS decreased the number of mice with tumors 
from $72.7 \%$ in wild type mice to $31.0 \%$ in those not expressing iNOS ${ }^{56}$.

It is estimated that there are about 14,000 new cases of esophageal cancer and that over 13,000 deaths from this malady occurs in the United States per year ${ }^{15}$. iNOS expression is highly associated with esophageal squamous cell carcinoma ${ }^{57-61}$. Barrett's esophageal is a premalignant condition arising from chronic reflux esophagitis and high levels of iNOS as well as COX-2 have been observed in this condition ${ }^{58,60-62}$. This has led to the speculation that iNOS and COX-2 are involved in Barrett's-associated neoplastic progression ${ }^{58,62}$. Animal models based on nitrosomethylbenzylamine induced esophageal cancer ${ }^{63}$ have shown that catalytic inhibitors of COX $-2^{64}$ as well as iNOS ${ }^{65}$ decreases cancer development. Pancreas cancer remains the fourth leading cause of death due to cancer in the Western World ${ }^{66}$ and about 31,860 new cases were diagnosed in the US this last year and nearly that many deaths, i.e. 31,270 , occurred due to this disease ${ }^{15}$. The 6 month survival is about $50 \%$ and the five-year survival after diagnosis is less than $5 \%{ }^{66}$. It has been known for several years that pancreatic cancer is associated with increased expression levels of iNOS and COX-2 when compared to normal pancreatic tissue ${ }^{67-71}$. The most insightful study of the importance of iNOS and NO production on pancreatic carcinoma growth and their resistance to anti-cancer drugs was recently reported ${ }^{72}$. This study demonstrated that pancreatic fibroblasts caused increased IL- $1 \beta$ secretion by the tumor cells, which then acted upon the fibroblasts to cause the upregulation of iNOS causing enhanced NO secretion, which then acted upon the tumor cells to mediate their resistance to etoposide-induced apoptosis. These results show that bystander stromal cells act to enhance the resistance of tumor cells to anti-cancer drugs. It also showed that the primary agent responsible is NO produced by the stromal fibroblast cells, which were induced to produce it by the IL- $1 \beta$ cytokines produced by the tumor cells. Prevention of iNOS expression by the stromal fibroblasts may help break the paracrine cycle, thus making the tumors more susceptible to anti-cancer agents.

\section{Animal Model Studies Evaluating iNOS/NO in Cancer Development}

One of the most important early experiments conducted demonstrating the importance of iNOS and NO in cancer development was done by Moncada's group ${ }^{11}$. They utilized DLD-1 human colon adenocarcinoma cells raised within nude mice from which they isolated a cell line (w/tR) which then was transfected with iNOS. They showed that this cell line (iNOS-19), which was shown to have functional iNOS, grew significantly slower in culture than the original cell line w/tR. Significantly however, they discovered that the iNOS19 cells grown in nude mice produced tumors that yielded significantly higher mass than the tumors arising from w/tR cells lacking iNOS expression. They also noted that the blood vessel volume of the tumors from iNOS-19 cells was 5-fold higher than the blood vessel volume of the tumors from the $\mathrm{w} / \mathrm{tR}$ cells. Therefore they showed that iNOS in tumor cells significantly enhanced tumor size and angiogenesis of the tumors when compared to tumor cells not having an extra level of functional iNOS.

Kisley et al. ${ }^{73}$ examined the extent of urethane-induced lung tumorigenesis which developed in iNOS knock out mice, as compared to wild type controls capable of expressing iNOS. They noted a significant reduction in the number of tumors in the iNOS knockout mice compared to the wild-type mice. iNOS expression in the wild-type mice was in the lung tumors per se, as well as in clara cells, but there was very little in the uninvolved lung tissue, as well as in the non-urethane treated mice. Studies in several animal models have demonstrated the importance of NO and iNOS in the development of mammary gland carcinogenesis ${ }^{74-77}$. Mammary cancer development in $\mathrm{C} 3 \mathrm{H} / \mathrm{HeJ}$ mice utilizes implantation of a cell line (C3L5) that is highly metastatic in this model ${ }^{74}$. C3L5 cells grown in Matrigel were implanted in the inguinal region on one side, and Matrigel containing no cells on the contralateral side. Mice were then given either L-NAME, a competitive inhibitor of iNOS, in the diet, or D-NAME, a non-competitive inhibitor, as a control. Invasiveness and angiogenesis of the tumor was measured using the CD31 marker for the presence of new blood vessels. The results clearly showed that tumor cell invasiveness was decreased significantly when L-NAME was given compared to D-NAME. This clearly implicates the importance of iNOS in angiogenesis and invasiveness of mammary tumors in the mouse model. Histologially they demonstrated localization of eNOS and iNOS in the tumor region. A different more definitive study of the role of iNOS in mammary gland carcinogenesis in mouse was done by another group ${ }^{77}$. In this study endogenous mammary tumor development was mediated by the polyomavirus middle $\mathrm{T}$ antigen (PyV-mT) directed to the mammary gland in the C57BL/6 strain which either was capable of expressing iNOS or not. PyV-mT/iNOS ${ }^{-/-}$mice and PyV-mT/iNOS ${ }^{++}$ mice were evaluated regarding the rate of mammary tumor growth and iNOS, as well as eNOS expression, was monitored using western blot analysis of the mammary tissue. Their results showed that mammary tumor development was significantly delayed in the PyV-mT/ $\mathrm{iNOS}^{-/}$mice when compared to the $\mathrm{PyV}-\mathrm{mT} / \mathrm{iNOS}^{+/+}$mice, thus clearly implicating the importance of iNOS in mammary tumor development.

Probably the most extensive studies demonstrating the importance of iNOS and NO in animal models have come from those done on colon cancer development. The studies by Rao and Reddy's groups have provided excellent data to support the notion that inhibition of iNOS production slows down colon cancer development in the azoxymethaneinduced rat model, see for instance references ${ }^{37,78}$. Another approach in another model has produced supportive data. Ahn and Ohshima ${ }^{79}$ utilized the $\mathrm{Apc}^{\mathrm{min} /+}$ mice that develop excessive amounts of intestinal adenomas. Administering amino guanidine, a specific iNOS inhibitor, in the drinking 
water caused suppression of adenoma formation in the small intestine but not the large intestine. They also utilized iNOS gene knockout methods in this mouse model and noted that $\mathrm{Apc}^{\mathrm{min} /+}{ }_{\mathrm{iNOS}}{ }^{-/-}$mice as well as $\mathrm{Apc}^{\mathrm{min} /{ }^{+}} \mathrm{iNOS}^{-/+}$mice had significantly fewer adenomas than $\mathrm{Apc}^{\mathrm{min} /+} \mathrm{iNOS}^{+/+}$mice. This observation clearly implicates the importance of iNOS and NO in the development of intestinal adenomas. Recently it has been demonstrated that NO induces COX-2 in colorectal cancer cells ${ }^{41}$. The discovery that $\mathrm{NO}$ mediates the induction of COX-2 in colon carcinogenesis is very important for it makes it possible to establish the primary sequence of events where therapeutics could be developed to slow down or prevent the processes involved. Four critical points in the primary pathway are immediately apparent, i.e. A) catalytic inhibitors of COX-2 enzymes, B) inhibitors that prevent COX-2 gene induction, C) catalytic inhibitors of iNOS enzyme and D) inhibitors to prevent iNOS gene induction. Basic research activity in these four areas is presently ongoing. Rao and Reddy's groups have been the most active, primarily utilizing a rat model of colon cancer induced by azoxymethane $e^{33,34,36,37,39,80}$. They have shown in the same rat model that an iNOS catalytic inhibitor, $\mathrm{L}_{-} \mathrm{N}^{6}-(1-$ iminoethyl)lysine tetrazole-amide (SC-1), given in the diet decreased colon tumors in proportion to the amount of SC-1 present, and that this agent in combination with Celecoxib (a COX-2 enzyme inhibitor) was effective also in an additive manner ${ }^{81}$. Reddy summarized the work in this area, in the context of chemoprevention of colon cancer, and emphasized the importance of inhibition of iNOS and COX2 as possible therapeutics ${ }^{39}$. Another review drew a similar conclusion $^{40}$. Isoliquiritigenin, a natural flavonoid from licorice, decreased the expression of iNOS and COX-2, and inhibited preneoplastic aberrant crypt foci in the azoxymethane rat model of colon cancer ${ }^{38}$.

Studies on a rat model of esophageal tumorigenesis have shown the importance of iNOS and $\mathrm{NO}^{63,65}$. Observations in humans have shown a strong association of iNOS and enhanced NO production in esophageal cancers. Chen and Stoner conducted experiments with rats developing esophageal tumors caused by $\mathrm{N}$ nitrosomethylbenzylamine. They showed that administering a diet containing a pheylenethiourea derivative referred to as PBIT, a selective iNOS inhibitor, significantly decreased the esophageal cancer incidence as well as tumor multiplicity ${ }^{63,65}$. Very few definitive studies have been done on the importance of iNOS and NO in animal models of liver carcinogenesis. The best study thus far was conducted by Thorgiersson's group with c-Myc/TGF $\alpha$ transgenic mice that develops liver cancer within 6 to 8 months. They noted that administering $\alpha$-tocopherol in the diet caused a significant decrease in liver tumors and concomitantly a significantly decreased amount of iNOS was expressed as well as nitrotyrosine in livers of the mice ${ }^{82}$. There was a strong correlation of iNOS levels with the appearance of tumors in not only the c-Myc/TGF $\alpha$ transgenic mice but in the c-Myc as well as the TGF $\alpha$ transgenic mice also.

We have also detected increased NO in a choline-

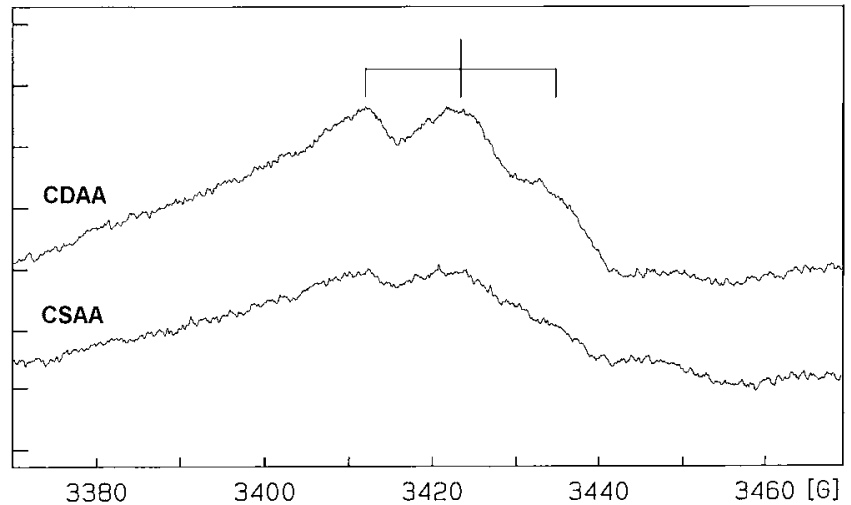

Fig. 1. EPR spectra of MGD-FE-NO in rats treated with either choline deficient amino acid defined (CDAA) or choline sufficient amino acid defined (CSAA) diets for 7 days. D- $N$ Methylglucamine dithiocarbamate (MGD) $(200 \mathrm{mg} / \mathrm{kg}$ )/iron sulfate $(20 \mathrm{mg} / \mathrm{kg})$ was injected intraperitoneally (ip) following cannulation of the bile duct under anesthesia (1.5$2 \%$ isoflurane).

deficient rat liver carcinogenesis model (see Figs. 1 and 2). A two-fold increase in NO was detected in the bile (bile duct cannulation) via electron paramagnetic resonance (EPR) spin trapping, as early as 1 week following dietary restriction of choline (Fig. 1). Flow cytometry analysis of isolated hepatocytes from CDAA diet-treated rats for 2 weeks, also indicated over a 2-fold increase in NO detection, compared to the CSAA controls (see Fig. 2). We had earlier demonstrated that isolated hepatocytes from rats placed on a choline-deficient diet for only 2 days had a population that produced enriched levels of NO which was suppressed by administering the synthetic antioxidant $\alpha$-phenyl-tert-butyl nitrone $(\mathrm{PBN})^{83}$. We also showed that $\mathrm{PBN}$ had anti-cancer activity in this model ${ }^{84-87}$. We showed that administering PBN as well as the 3-hydroxy and 4-hydroxyl derivatives in the diet caused selective enhanced killing of the cells within the preneoplastic lesions at 16 weeks but had no effect of the cells in the surrounding liver tissue ${ }^{84,85}$. We later surmised that the enhanced selective killing of the cells within the preneoplastic lesion by $\mathrm{PBN}$ and active derivatives was due to their suppression of $\mathrm{NO}$ formation therefore allowing the normal cellular stressors to enhance their apoptosis ${ }^{88}$. Therefore we see our results as indicating that intermediate levels of NO suppressed the death of the cells within the preneoplastic lesions and therefore contributed to the development of hepatocellular carcinoma in the rat choline deficient model.

\section{Nitric Oxide Formation and Reaction Chemistry}

Nitric Oxide has an unpaired free electron and therefore is a gaseous free radical formed by nitric oxide synthase enzymes utilizing L-arginine as substrate. The oxygen atom of NO comes from molecular oxygen and the nitrogen atom arises from one of the guanidino nitrogens of L-arginine (Fig. 

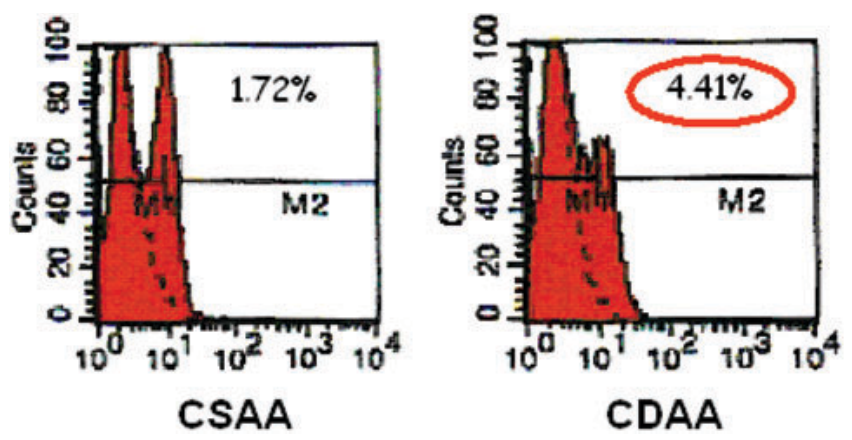

Fig. 2. Flow cytometry (FACS) expression of diaminofluorescein-2 diacetate (DAF-2DA) detected nitric oxide (NO) in isolated liver cells from CSAA and CDAA diet fed rats at 2 weeks.

\section{Formation and Properties of Nitric Oxide}<smiles>NC(=O)CCCNC(N)=O</smiles>

L-Arginine<smiles>N/C(=N/O)C(=O)NCCC[C@H](N)C(=O)O</smiles>

L-Hydroxy -Arginine

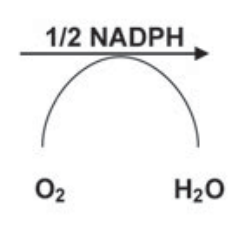<smiles>N#CC(=O)NCCC(N)C(N)=O</smiles>

L-Citrulline

Nitric Oxide Synthase (NOS) catalyzes formation of NO from L-Arginine

Nitric Oxide Synthases $\left\{\begin{array}{l}\text { eNOS }-\mathrm{Ca} / \text { calmodulin dependent } \\ \text { nNOS }-\mathrm{Ca} / \text { calmodulin dependent } \\ \text { iNOS }-\mathrm{Ca} \text { independent, inducible gene, larger sustained levels of NO }\end{array}\right.$

NO is a free radical

$\pi * 2 p$

Orbital

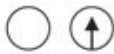

NO.
(4) (4)

$\mathrm{O}_{2}$

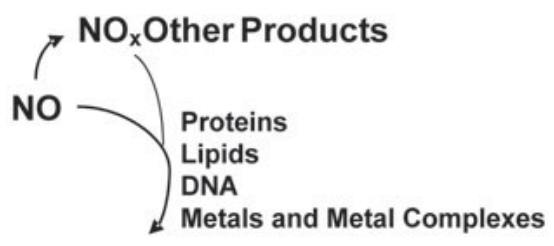

\section{Products and Consequences}

S-Nitrosylation, Nitration Adducts of lipids, DNA, proteins Altered signal transduction processes Many other consequences

Fig. 3. Reaction demonstrating the formation of NO from L-arginine catalyzed by nitric oxide synthase (NOS). List of the three types of NOS and their properties as well as the occupancy of the $\pi^{*} 2 \mathrm{P}$ orbitals demonstrating the properties of NO different than $\mathrm{O}_{2}$ and that $\mathrm{NO}$ is a free radical. Listing of the reaction products of $\mathrm{NO}$ with biological molecules and summarizing some of the consequences.

3). There are three nitric oxide synthase (NOS) enzymes formally referred to as NOSI, NOSII and NOSIII for eNOS, iNOS and nNOS or so-called endothelial NOS, inducible NOS and neuronal NOS, respectively. Both eNOS and nNOS are dependent on the presence of calcium to trigger NO synthesis but iNOS synthesizes NO independent of the presence of calcium and therefore produces NO in much larger sustained amounts than are formed by the other two enzymes. The cancer development literature is more focused on the role of iNOS than the other two NOS isofroms. $\mathrm{NO}$ and the various products originating from
iNOS react with proteins, nucleic acids and lipids thus mediating biological effects the consequences of which are still being elucidated.

Some of the reactions NO may undergo readily are shown in Fig. 4. NO reacts at diffusion limited rates with superoxide, $\mathrm{O}^{-}$, to yield peroxynitrite which then will react with many biological molecules. NO reacts via its oxidation species, nitronium ion, with glutathione (GSH) and specific protein cysteine residues to form S-nitrosoglutathione and proteins S-NO adducts respectively. The formation of cysteine S-nitrosylation adducts are commonly referred to as 
Nitric Oxide Reactions in Biology

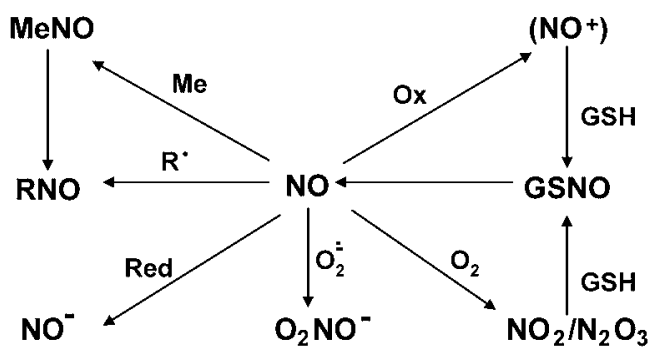

\footnotetext{
Me - Metals or metal complexes

R' - Free Radicals

Red - Reduction to nitroxyl anion (NO-)

$\mathrm{Ox}$ - Oxidation to nitronium ion $\left(\mathrm{NO}^{+}\right)$

$\mathrm{O}_{2} \mathrm{NO}$ - Peroxynitrite

GSH : Glutathione
}

Fig. 4. Some of the many possible reactions of NO that may happen to biological systems.

SNO products. $\mathrm{NO}$ also reacts with molecular oxygen to form $\mathrm{NO}_{2}$ and $\mathrm{N}_{2} \mathrm{O}_{3}$ which then will react with $\mathrm{GSH}$ or with protein cysteine residues to form protein-S-NO adducts. NO reacts with transition metal complexes to form $\mathrm{NO}$ complexes of these species. An example of this is the binding of NO to guanylate cyclase to cause the increased synthesis of cyclic GMP. It is also well known that NO binds to Fe-S complexes some of which are important cofactors in enzymes as for example the mitochondrial respiratory chain. NO will also react with other free radicals $\left(\mathrm{R}^{\circ}\right)$ to form nonradical products, i.e. RNO. In short, NO is involved in biological systems in many different reaction pathways. This review is more concerned with NO reactions with proteins and how these reactions influence cancer development. The most studied amino acid residues that react with $\mathrm{NO}$ are cysteine and tyrosine.

\section{Protein cysteine $S$-nitrosylation}

The reaction of protein cysteine residues to form NO reaction products is complex and is still being elucidated. Many reaction products are formed by the reaction of NO in its various oxidation states with protein cysteine, as was noted by Vaananen et al. ${ }^{89}$. In their study various chemical sources of NO (i.e. various oxidative state derivatives) were used in papain inactivation. Papain was inactivated with $\mathrm{IC}_{50}$ values of $0.62,2.3,54$ and $80 \mu \mathrm{M}$ for Angeli's salt, SIN1 , papanonoate, and nitrosoglutathione respectively. Some cysteine adducts formed were reversible with dithiothreitol (DTT), and some were not. Inactivation of papain was shown to depend upon chemical modification of the active site cysteine, Cys25, which is part of the spatially positioned Cys25-His159-Apn 175 catalytic triad of this protease ${ }^{90}$. The active Cys 25 of papain will also react with S-nitrosthiols to form Cys-S-R adducts, which also inactivates the enzyme ${ }^{91}$. The fluorescent S-nitroso probe (S-nitroso-5dimethylaminonaphthalene-1-sulfonyl) was used to demonstrate that the NO donor was bound to the protein as the Cys-S-R complex ${ }^{91}$. Papain as a cysteine protease shares many features of the important mammalian cysteine proteases cathepsin $\mathrm{B}, \mathrm{H}, \mathrm{L}$ and $\mathrm{S}$ and the calpains ${ }^{92}$. It should be noted that cysteine proteases are involved in cellular apoptosis, and importantly several members of this group (caspases $1,2,3,4,6,7$ and 8 ) have been shown to reversibly inactivated by $\mathrm{NO}^{93}$.

The active site triad of papain is quite similar to that of the enzyme dimethylarginine dimethylamino hydrolase (DDAH), which has an active site traid of Cys 249-His162Glu144 ${ }^{94}$. DDAH degrades $\mathrm{N}^{\mathrm{G}}, \mathrm{N}^{\mathrm{G}}$-dimethyl-L-arginine (ADMA) and $\mathrm{N}^{\mathrm{G}}$-monomethyl-L-arginine (L-NMMA) to citrulline plus dimethylamine and monomethylamine respectively. ADMA and L-NMMA are endogenous inhibitors of NOS enzymes ${ }^{95}$. Importantly it has been demonstrated that DDAH is reversibly inactivated by $\mathrm{NO}^{94,96}$. The fact that both papain and DDAH as well as many other enzymes are inactivated by NO is consistent with the general observations that the high specificity of Snitrosylation of specific cysteines in proteins is dictated by the critical positioning of acidic and basic amino acids on either side of the target cysteine ${ }^{97,98}$. In fact, a general examination of the 100 or so proteins that have been shown to be S-nitrosylated in biological systems, see for example ${ }^{99-}$ ${ }^{101}$, have demonstrated that they have a degenerate consensus motif as such $\mathrm{X}(\mathrm{K} / \mathrm{R} / \mathrm{H}) \mathrm{C}(\mathrm{D} / \mathrm{E})$. Thus the target cysteine is juxtaposed between a basic amino acid on one side, and an acidic amino acid on the other side ${ }^{102}$. It should be noted that the consensus motif can be accomplished by juxtaposing the basic and acidic amino acids near the target cysteine, either spatially as dictated by the protein conformation, or in a defined linear sequence. The consensus motif causes the cysteine $\mathrm{SH}$ to become acidic, and thus exist as the thiolate anion, therefore making it highly susceptible to Snitrosylation. An example of the acid-base motif is illustrated by Hess et al. ${ }^{98}$ with the reactive cysteine of aquaporin Cys 189 spatially positioned between the acidic Asp 128 and the basic His 180. The Cys 189 thiolate anion is positioned in space 4 angstroms from Asp 128 as well as His $180^{98}$. Hess et al. ${ }^{98}$ summarized the molecular reaction mechanisms involved in the S-nitrosylation of the protein target cysteine (Fig. 5). It is considered that S-nitrosylation can be mediated by either a transition metal complex with $\mathrm{NO}$ denoted as M-NO, or an oxidation species of NO noted as $\mathrm{NO}_{\mathrm{x}}$ formed by the reaction of $\mathrm{O}_{2}$ with $\mathrm{NO}$ that occurs more readily within a protein hydrophobic region. Nedospasov et al. ${ }^{103}$ considers that $\mathrm{N}_{2} \mathrm{O}_{3}$ is the critical nitrosylating species for protein cysteines as dictated by the following equations: $2 \mathrm{NO}^{\circ}+\mathrm{O}_{2} \rightarrow 2^{\circ} \mathrm{NO}_{2}$; ${ }^{\circ} \mathrm{NO}_{2}+\mathrm{NO}^{\bullet} \leftrightarrow$ $\mathrm{N}_{2} \mathrm{O}_{3}$ (in hydrophobic phase) and $\mathrm{N}_{2} \mathrm{O}_{3}+\mathrm{H}_{2} \mathrm{O} \rightarrow 2 \mathrm{HNO}_{2}$ (in water). The formation of $\mathrm{N}_{2} \mathrm{O}_{3}$ is possible due to the high solubility of $\mathrm{NO}$ and $\mathrm{O}_{2}$ in the hydrophobic phase. Protein cysteines can also be S-nitrosylated by nitrosothiol 
Mechanisms of Protein S-Nitrosylation*

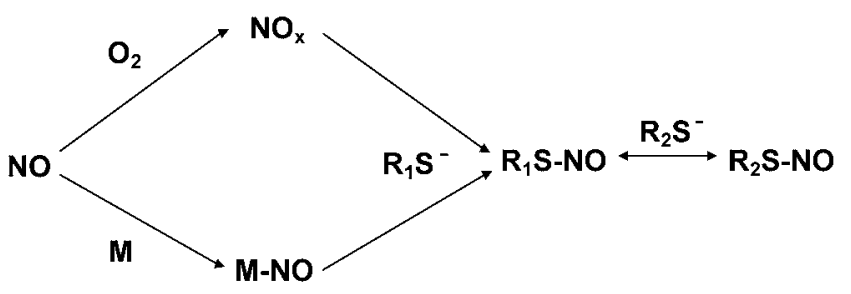

M - transition metal

$\mathrm{NO}_{x}$ - Most likely $\mathrm{N}_{2} \mathrm{O}_{3}$ or [ $\mathrm{NO}^{+} \ldots \mathrm{NO}_{2}$ ]

Potentiated by hydrophobic environment

$R_{1} S^{-}, R_{2} S^{-}$- Protein cysteine sulfhydryls

Fig. 5. Mechanisms of the formation of S-nitrosylation products with acidic cysteine residues in proteins. The thiolate anion of cysteine is very reactive with $\mathrm{NO}$ which exists as $\mathrm{N}_{2} \mathrm{O}_{3}$ or $\left[\mathrm{NO}^{+}----\mathrm{NO}_{2}\right]$ in a hydrophobic environment or as an active species when associated with a transition metal. Reaction taken from Hess et al. ${ }^{98}$.

compounds such as nitroso glutathione ${ }^{98}$.

The S-nitrosylation of some protein tyrosine phosphatases (PTPs) has been demonstrated ${ }^{102,104-106}$. It should be noted that even though NO mediates inactivation of PTP1B ${ }^{104,106,107}$, it can be reactivated by chemical treatment with dithiothreitol, but there is nothing known about possible natural occurring systems that may reactivate the SNO modified proteins. Gaston et al. ${ }^{108}$ recently presented an excellent review with pertinent information related to this issue. With regard to nitrosoglutathione (GSNO) there are several pathways whereby it has been shown to be metabolized. GSNO is degraded in a NADH/ NADPH-dependent process by a rat liver cytosolic enzyme that has been identified as alcohol dehydrogenase (ADH) class III enzyme ${ }^{109}$. This enzyme has GSH-dependent formaldehyde dehydrogenase (GDFDH) activity also. However it has a $\mathrm{Km}$ for GSNO of $\sim 20 \mu \mathrm{M}$ and a Kcat $/ \mathrm{Km}$ of $94,300 \mathrm{mM}^{-1} \mathrm{~min}^{-1}$, which is much higher than the other ADHIII substrates ${ }^{108,109}$. Based on this and all the other evidence $^{109}$ it is considered that ADHIII is the primary enzyme responsible for metabolizing $\mathrm{GSNO}^{109,110}$, and that the two enzymes, ADHIII and GDFDH, are the same ${ }^{108}$. In addition to ADHIII, the $\mathrm{Cu} / \mathrm{Zn}$ superoxide dismutase enzyme ( $\mathrm{Cu} / \mathrm{Zn} \mathrm{SOD})$ has been shown to effectively degrade GSNO in the presence of GSH with a $\mathrm{Km}$ of $5.6 \mu \mathrm{M}^{111}$. Additionally thioredoxin in the presence of NADPH will degrade GSNO to GSH and NO with a $\mathrm{Km}$ value of 60 $\mu \mathrm{M}^{112}$. Xanthine Oxidase in the presence of hypoxanthine will metabolize GSNO as well as nitrosocysteine (CysNO) with a $\mathrm{Km}$ in the range of 300-700 $\mu \mathrm{M}$ respectively ${ }^{113}$.

The above points highlight another area of considerable uncertainty; namely what are the exact molecular events and the mechanisms dictating why specific cysteines in specific proteins become nitrosated within a cell where there are so many other potential available thiol groups. First it is quite clear that the reason why specific cysteines are S-nitrosated is dictated by the amino acids spatially positioned very close to the target thiol group such that it assumes acidic character making it labile to nitrosation. However the most uncertainty arises regarding the nitrosating entity. The $\mathrm{Km}$ for reaction of GSNO to inactivate papain is $60 \mu \mathrm{M}^{89}$. As noted above the $\mathrm{Km}$ of GSNO reaction with ADHIII is 20 $\mu \mathrm{M}$ and with CuZn SOD is $5.6 \mu \mathrm{M}$, therefore it is unlikely that GSNO within a cell exists long making it unlikely that it is an important protein S-nitrosylating species. Supporting this notion are the observations that S-nitrosylated proteins are present in biological samples even though GSNO is undetectable. Whereas in ADHIII knockout cells Snitrosylated proteins increase dramatically but GSNO is only then detectable ${ }^{108,110}$. Based on the above logic then, if the target cysteine exists in a hydrophobic domain of the protein it is highly likely that $\mathrm{N}_{2} \mathrm{O}_{3}$ is the reacting species simply because $\mathrm{NO}$ and $\mathrm{O}_{2}$ are much more soluble in hydrophobic domains ${ }^{103} \cdot \mathrm{N}_{2} \mathrm{O}_{3}$ can be written as $\left[\mathrm{NO}^{+}---\mathrm{NO}^{-}{ }_{2}\right]$ thus making it clear that the thiolate sulfur reacts with the nitrosonium cation.

\section{S-nitrosylation of Critical Proteins Enhance Cancer Development}

Our survey of the existing literature provides us the perspective that there are at least 4 to 5 critical proteins that can help explain on a mechanistic basis how NO, at intermediate levels, mitigates tumor development. The critical proteins and a brief description of how they enhance tumor development are discussed briefly here and summarized in Fig. 6. A) NO mediates S-nitrosylation of specific caspases that are involved in apoptosis processes, thus preventing processes which would normally cause the death of cancer cells, and therefore allows continued growth and development of tumors. B) NO mediates the Snitrosylation of the DNA repair enzyme OGG1 $1^{114}$, thereby preventing the repair of oxidative adducts such as 8hydroxy-2'deoxyguanosine, which then allows mutagenic lesions to be incorporated into DNA therefore leading to mutational events enhancing tumor development. C) NO mediates the S-nitrosylation of the PTEN protein ${ }^{115}$ that acts as a tumor suppressor in several tumors. The results of PTEN inactivation cause enhanced AKT signal transduction processes which is known to enhance cancer development. D) NO mediates the S-nitrosylation of Bcl-2, thus preventing the proteosomal degradation of this protein, and thus resulting in higher levels of $\mathrm{Bcl}-2^{116}$ which acts to prevent apoptosis. E) NO mediates the S-nitrosylation of methionine adenosyltransferase (MAT 1/111) leading to decreased levels of S-adenosyl-methionine which enhances cell proliferation. Inactivation of MAT 1/111 is most important in the case of hepatocellular carcinoma development. F) NO mediates the activation of the Ras pathway which is 
Proteins S-Nitrosylated which Enhance Cancer Development

Proteins S-Nitrosylated

Specific Caspases

$\mathrm{Bcl}-\mathbf{2}$

OGG1 DNA Repair Enzyme

PTEN Tumor Suppressor Protein

Liver Methionine Adenosyl Transferase
Consequences of Inactivation

Inactivation of apoptosis mechanisms prevent cellular apoptosis

Prevents proteosomal loss of $\mathrm{Bcl}-2$. $\mathrm{Bcl}-2$ buildup, prevents apoptosis

Causes buildup of 8-OHdG enhances mutations

Enhances Akt-mediated signaling enhances oncogenesis

Decreases S-adenosyl methionine levels causes enhanced cell proliferation

Fig. 6. List of the possible proteins which if they are S-nitrosylated by NO enhance the development of cancer by the mechanisms listed.

important in the development of many tumors. In the sections below we amplify the background rationale for some of these six key notions noted above.

\section{S-nitrosylation inhibition of apoptosis in cancer cells}

Several careful studies have shown that apoptosis of tumor cells is controlled by S-Nitrosylation of specific proteins. The most definitive studies have been done with human colon carcinoma cells ${ }^{117}$, human cholangiocarcinoma cells $^{118}$, human breast carcinoma cells ${ }^{119}$, and human melanoma cells ${ }^{23}$. Kim and Tannenbaum utilized HT-29 colon carcinoma cells to show that S-nitrosylation of procaspase-9 was the key event that protected these cells from TNF $\alpha$ plus interferon $\gamma(\mathrm{TNF} \alpha / \operatorname{Ifn} \gamma)$ induced apoptosis ${ }^{117}$. When the cells were exposed to the nitric oxide synthase inhibitor $\mathrm{N}^{\mathrm{G}}$-methyl-L-arginine prior to TNF $\alpha / \mathrm{Ifn} \gamma$ treatment then apoptosis occurred. Utilizing a biotin switch method $^{120}$ specific S-nitrosylation of procaspase-9 was demonstrated to be directly correlated with decreased apoptosis. It should be noted that plated tumor cells may respond to nitrosative stress in a different manner than those undergoing fluid shear stress similar to that expected when malignant cells are traveling through the blood stream, i.e. see for example the studies conducted by Laguinge et al. on 3 -D rotated colorectal carcinoma cells ${ }^{121}$.

As with the studies on colon carcinoma cells noted above, Torok et al. ${ }^{118}$ showed that S-nitrosylation of caspase-9 in cholangiocarcinoma cells is directly associated with protecting them from apoptosis induced by etoposide. The source of NO in the cells was either from transfected iNOS or from an exogenous donor S-nitroso-N-acetyl-D,Lpenicillamine (SNAP). The arguments presented is that external sources of NO are meaningful in the context of cholangiocarcinoma because primary sclerosing cholangitis, a chronic inflammatory condition, is the main identifiable risk factor for this tumor and that enhanced NO production is associated with inflammation. Therefore exogenous sources are meaningful under this condition ${ }^{118}$.

Utilizing T46D human breast carcinoma cells Radisavljevic ${ }^{119}$ demonstrated that inhibition of iNOS using $\mathrm{N}^{\mathrm{G}}$-monomethyl-L-arginine caused enhanced apoptosis. Apoptosis signaling was shown to be independent of caspase-3 as well as the PI3K/AKT pathway. In another study using T47D cells Kampa et al. ${ }^{122}$ also showed that inhibition of iNOS induction enhanced apoptosis in these cells. Growth of MCF-7 cells, another human breast cancer cell line, was shown to be dependent on arginine ${ }^{123}$ and that cell growth, not protein synthesis per se, but due to its role as a substrate for nitric oxide synthase to produce NO. Several studies in humans ${ }^{124-126}$ have shown a general positive correlation between iNOS expression with severity of breast cancer. The conclusions were that iNOS was involved in angiogenesis, invasion and metastasis of the tumor growth ${ }^{124-127}$. These predictions have been born out in animal studies also ${ }^{75,76}$. Additionally, studies with an iNOS negative mouse model compared to the normal iNOS positive control mice have shown that mammary tumor development and invasiveness was more rapid in the normal iNOS expressing animals ${ }^{77}$.

A careful study of human melanoma cells done in comparison to normal melanocytes demonstrated that both cells expressed iNOS at about equal levels ${ }^{23}$. However addition of aminoguanidine, a selective inhibition of iNOS, to both cells demonstrated that this led to apoptosis of melanoma cells but not to the normal melanocytes. They show that apoptosis in melanoma cells involved caspase 3 activation, alteration of mitochondrial membrane potential and down regulation of $\mathrm{Bcl}-2$ and the upregulation of a series of genes involved in apoptosis including Bax, caspase-1, caspase- 3 , caspase- 6 , gadd $45 \beta, \operatorname{mdm} 2$ and TRAIL ${ }^{23}$. The data in this study clearly showed that iNOS activity is important in melanoma cell survival. Another more recent study, where several melanoma cell lines were examined in comparison to normal melanocytes, showed that in contrast 
to the normal cells which responded to TNF $\alpha$, Inf $\gamma$ and LPS stimulation by showing a strong positive iNOS induction, the melanoma cells did not ${ }^{24}$. However, contrary to normal melanocytes the melanoma cell lines already showed weak iNOS expression. In a careful study evaluating iNOS and MDA-7 (melanoma differentiation association gene, considered a novel tumor suppressor gene) in 81 tumor samples consisting of 38 primary melanomas and 43 metastatic melanomas demonstrated that there was a significant negative correlation $(\mathrm{P}=0.03)$ of iNOS expression with MDA-7 expression ${ }^{22}$. In other words when MDA-7 was expressed iNOS was not expressed. This study was followed up with a companion series of experiments with melanoma cell lines having adenoviral vector transfected MDA-7 gene. In these studies they demonstrated MDA-7 expression caused a decreased expression of iNOS $^{22}$. They further showed that STAT-3 modulated expression of interferon regulating factors 1 and 2 is regulated by MDA-7 and that this may mediate iNOS expression in these cells.

\section{PTEN inactivation by S-nitrosylation}

Phosphatase/tension homolog on human chromosome ten (PTEN) has emerged over the last few years as one of the most important tumor suppressor genes. The tumor suppressor function of PTEN is largely associated with suppression of cell growth and survival signaling through the phosphatidylinositol (PI) 3-kinase/Akt pathway ${ }^{128-136}$. It was discovered in 1997 as a multiple mutated gene in many advanced cancers including those of breast, prostate, endometrial and brain tissue $e^{137-141}$. Mutation of PTEN is a marker for glioblastoma and is associated with Cowden's disease and Bannayan-Zonana syndromes, which are characterized by multiple benign tumors, and a risk for breast and thyroid. PTEN cleaves the phosphate group from the 3'-OH position of the inositol head group of $\mathrm{PIP}_{3}$ and therefore opposes PI 3-kinase signaling ${ }^{135}$. PI 3-kinase is a ubiquitous intracellular kinase upstream of many signaling pathways related to several cell functions including growth and survival. Like PTP1B, the PTEN active site thiolate group has been shown to be susceptible to oxidation by $\mathrm{H}_{2} \mathrm{O}_{2}{ }^{142}$. Unlike PTP1B, but similar to some related phosphatases, this oxidation results in the formation of an intramolecular disulfide bond with a "back-door" cysteine residue (Cys71) on another domain. We have postulated that the PTEN active site cysteine could be S-nitrosylated and therefore cause inactivation of the enzyme. This has subsequently been demonstrated ${ }^{115}$.

\section{Bcl-2 S-nitrosylation and cancer cell apoptosis}

B-cell lymphoma-2 (Bcl-2) is a key protein that regulates apoptosis by the mitochondrial dependent pathway. Bcl-2 prevents apoptosis by A) forming heterodimers with the proapotosis protein $\mathrm{Bax}, \mathrm{B}$ ) by inhibition of cytochrome $\mathrm{C}$ release from mitochondria and C) by regulating mitochondria membrane potential, and therefore increased levels of Bcl-2 are antiapoptotic. Bcl-2 levels are controlled by its rate of synthesis, as well as by its rate of degradation by the ubiquitin-proteasomal pathway. Azad et al. ${ }^{116}$ have demonstrated that NO causes Snitrosylation of Bcl-2 in the human lung cancer cell line $\mathrm{NIH}-\mathrm{H} 460$ and this prevents the ubiquitin-proteosomal degradation of Bcl-2, thus increasing its level and preventing $\mathrm{Cr}$ (VI)-mediated apoptosis of these cells. Bcl-2 Snitrosylation occurs on cys ${ }^{158}$ and cys $^{229}$ of this protein and is mediated by either endogenous production of NO or by addition using external donors. They also discovered that treatment of H460 cells with the stress inducers Fas ligand or buthionine sulfoxide also induced Bcl-2 S-nitrosylation. Several observations clearly demonstrate that nitric oxide from iNOS involving Bcl-2 is important in preventing normal B-cell lymphocyte apoptosis ${ }^{143}$, as in human B-cell lymphomas ${ }^{144-146}$. In the case of the treatment of B-cell lymphomas with resveratrol, it was shown to prevent iNOS expression, to cause decreased expression levels of Bcl-2, and to enhance cellular apoptosis ${ }^{145,146}$. Intravenous administration of natural polyphenols to mice bearing metastatic B16 melanomas enhanced apoptosis as well as decreased Bcl-2 expression in the metastatic cells involving nitric oxide dependent processes ${ }^{147}$. Although not formally proven that S-nitrosylation of Bcl-2 was involved in all the cases, this probably explains the mechanistic basis of these observations. Growth of spontaneous B-cell lymphoma in SJL mice is also highly correlated with iNOS expression ${ }^{148}$.

\section{S-nitrosylation of liver methionine adenosyltransferase}

It is highly likely that NO-mediated inactivation of liver methionine adenosyltransferase (MAT I/III) plays a major role in choline deficiency-mediated HCC development. The processes are involved in methylation of biological molecules is expected to be considerably altered in the choline deficiency (CD) liver because a major dietary supply of methyl groups (choline) is absent and another one (methionine) is significantly decreased. About $85 \%$ of the total methylation ${ }^{149}$ and $48 \%$ of total methionine metabolism occurs in the liver ${ }^{150}$. S-adenosylmethionine (SAMe, a product of MAT I/III), is the primary methyl donor substrate. Mato's lab, over the last 10 years, demonstrated that NO mediates inactivation of the MAT I/III expressed in the adult liver by S-nitrosylation ${ }^{149,151-156}$. Hepatic MAT exists in an oligomeric state, and both MAT I as well as MAT III have been shown to be S-nitrosylated, thus inhibiting enzymatic activity ${ }^{149,152-155}$. Nitric Oxide has been demonstrated to also inactivate MAT I/III in vivo ${ }^{157}$. Adult MAT (MAT I/III) is coded by the MAT1A gene. Mato's group demonstrated that knockout mice lacking this gene were predisposed to liver injury, exhibited increased expression of genes involved in cellular proliferation ${ }^{158}$, had impaired liver regeneration, had lower levels of SAMe, and spontaneously developed hepatocellular carcinomas ${ }^{159,160}$. S-nitrosylation of MAT I/III significantly decreased the levels of SAMe, and sensitized rat hepatocytes to enhanced proliferation $^{150,161,162}$, which is mediated by hepatocyte growth factor scatter factor (HGF), and probably involves 
IGF-1 priming ${ }^{163}$. HGF is turned on by lower levels of $\mathrm{SAMe}^{150}$. Liver cell proliferation caused by MAT I/III inactivation requires another MAT enzyme, MAT II, that is encoded by the constitutive MAT2A gene ${ }^{150,164}$. MAT II is expressed at low levels in the liver except in the case of pathological conditions where it is upregulated ${ }^{149,150}$. NO mediated S-nitrosylation of MAT I/III lowers SAMe levels that triggers the enhanced expression of MAT II, which is insensitive to NO-mediated S-nitrosylation. MAT II produces much lower levels of SAMe. Normal higher levels of SAMe are required to maintain the normal liver metabolic state but lower levels of SAMe produced by MAT II mediates a control switch that regulates liver function ${ }^{150}$ that results in cell proliferation. It is known that choline deficiency causes liver fibrosis and cirrhosis as well as decreased levels of S-adenosylmethionine ${ }^{165,166}$. It is also known that enhanced iNOS expression occurs in liver cirrhosis $^{167-170}$. S-nitrosylation of MAT I/III in the CD livers probably accounts for the decreased SAMe levels that have been observed ${ }^{165}$.

\section{Ras pathway in cancer development}

The Ras pathway is frequently activated in human cancer ${ }^{171}$ and is considered to play a critical role in many aspects of tumorigenesis ${ }^{172}$. Activation of Ras can occur by signal transduction processes triggered by specific growth factor binding to receptors that become tyrosine phosphorylated $^{173}$ setting up signal transduction processes. In about $30 \%$ of human cancers, mutations occur in the Ras gene protein $\left(\mathrm{P}_{21}{ }^{\text {ras }}\right)$ that causes it to be in a continuously activated state ${ }^{173}$. The Ras activation pathway primarily involves the following activation sequence Ras/Raf/Mek/ Erk $^{172,173}$, however Ras activation can also influence other pathways, including $\mathrm{Akt}^{171,173}$, which is also important in cancer development. It has been known for many years that NO activates Ras to enhance guanine nucleotide exchange ${ }^{174-179}$. The first experiments demonstrating that NO enhances guanine nucleotide exchange was done by exposing jurkat cells to NO gas ${ }^{174}$. Subsequent studies have been done using isolated proteins inactivated with chemical NO donors. NO-mediated Ras activation has been shown to mediate signal transduction processes in cells including $\operatorname{Raf}^{180}$ and Erk activation ${ }^{181,182}$ leading to many different effects depending on the specific cells ${ }^{180,182-185}$. It appears that Ras mutations do not normally occur in human hepatocellular carcinoma development ${ }^{186}$ but it is quite clear that the Ras pathway is activated, however as evidenced by significantly enhanced Raf overexpression and enhanced activation ${ }^{187,188}$. The Raf kinase is an important target for anticancer therapeutics ${ }^{172}$.

Acknowledgements: The studies leading to this review were funded in part by NIH grant RO1CA82506, OCAST fMRI-002 and a grant from the Japan Food Chemical Research Foundation. We are very grateful to many colleagues who helped generate the data for the original publications and to Donna Howell who helped with the manuscript preparation and graphics.

\section{References}

1. Hibbs JB Jr, Taintor RR, Vavrin Z, and Rachlin EM. Nitric oxide: A cytotoxic activated macrophage effector molecule. Biochem Biophys Res Commun. 157: 87-94. 1988.

2. Larmonier N, Ghiringhelli F, Larmonier CB, Moutet M, Fromentin A, Baulot E, Solary E, Bonnotte B, and Martin F. Freshly isolated bone marrow cells induce death of various carcinoma cell lines. Int J Cancer. 107: 747-756. 2003.

3. Hibbs JB Jr, Vavrin Z, and Taintor RR. L-Arginine is required for expression of the activated macrophage effector mechanism causing selective metabolic inhibition in target cells. J Immunol. 138: 550-565. 1987.

4. Hibbs JB Jr, Taintor RR, and Vavrin Z. Macrophage cytotoxicity: Role for L-arginine deiminase and imino nitrogen oxidation to nitrite. Science. 235: 473-476. 1987.

5. Drapier JC and Hibbs JB Jr. Murine cytotoxic activated macrophages inhibit aconitase in tumor cells. J Clin Invest. 78: 790-797. 1986

6. Hibbs JB Jr, Taintor RR, and Vavrin Z. Iron depletion: Possible cause of tumor cell cytotoxicity induced by activated macrophages. Biochem Biophys Res Commun. 123: 716-723. 1984.

7. Granger DL, Taintor RR, Cook JL, and Hibbs JB Jr. Injury of neoplastic cells by murine macrophages leads to inhibition of mitochondrial respiration. J Clin Invest. 65: 357-370. 1980

8. Ignarro LJ, Buga GM, Wood KS, Byrns RE, and Chaudhuri G. Endothelium-derived relaxing factor produced and released from artery and vein is nitric oxide. Proc Natl Acad Sci USA. 84: 9265-9269. 1987.

9. Palmer RMJ, Ferrige AG, and Moncada S. Nitric oxide release accounts for the biological activity of endotheliumderived relaxing factor. Nature. 327: 524-526. 1987.

10. Furchgott RF. Endothelium-derived relaxing factor: discovery, early studies, and identification as nitric oxide. Biosci Rep. 19: 235-251. 1999.

11. Jenkins DC, Charles IG, Thomsen LL, Moss DW, Holmes LS, Baylis SA, Rhodes P, Westmore K, Emson PC, and Moncada S. Roles of nitric oxide in tumor growth. Proc Natl Acad Sci USA. 92: 4392-4396. 1995.

12. Kirk P, Hoffmann G, and Rieder J. Inducible nitric oxide synthase - time for reappraisal. Curr Drug Targets Inflamm Allergy. 1: 89-108. 2002.

13. Rahman MA, Dhar DK, Yamaguchi E, Maruyama S, Sato T, Hayashi H, Ono T, Yamanoi A, Kohno H, and Nagasue $\mathrm{N}$. Coexpression of inducible nitric oxide synthase and COX-2 in hepatocellular carcinoma and surrounding liver: possible involvement of COX-2 in the angiogenesis of hepatitis C virus-positive cases. Clin Cancer Res. 7: 13251332. 2001

14. Ikeguchi M, Ueta T, Yamane Y, Hirooka Y, and Kaibara N. Inducible nitric oxide synthase and survivin messenger RNA expression in hepatocellular carcinoma. Clin Cancer Res. 8: 3131-3136. 2002.

15. Am Cancer Soc. American Cancer Society Cancer Facts and Figures 2004. Atlanta. 1-10. 2004.

16. Aaltomaa SH, Lipponen PK, and Kosma VM. Inducible nitric oxide synthase (iNOS) expression and its prognostic value in prostate cancer. Anticancer Res. 21: 3101-3106. 
2001.

17. Wang J, Torbenson M, Wang Q, Ro JY, and Becich M. Expression of inducible nitric oxide synthase in paired neoplastic and non-neoplastic primary prostate cell cultures and prostatectomy specimen. Urol Oncol. 21: 117-122. 2003.

18. Nelson WG. Agents in development for prostate cancer prevention. Expert Opin Investig Drugs. 13: 1541-1554. 2004.

19. Aaltomaa SH, Lipponen PK, Viitanen J, Kankkunen JP, Ala-Opas MY, and Kosma VM. The prognostic value of inducible nitric oxide synthase in local prostate cancer. BJU Int. 86: 234-239. 2000.

20. Klotz T, Bloch W, Volberg C, Engelmann U, and Addicks $\mathrm{K}$. Selective expression of inducible nitric oxide synthase in human prostate carcinoma. Cancer. 82: 1897-1903. 1998.

21. Wartenberg M, Schallenberg M, Hescheler J, and Sauer H. Reactive oxygen species-mediated regulation of eNOS and iNOS expression in multicellular prostate tumor spheroids. Int J Cancer. 104: 274-282. 2003.

22. Ekmekcioglu S, Ellerhorst JA, Mumm JB, Zheng M, Broemeling L, Prieto VG, Stewart AL, Mhashilkar AM, Chada S, and Grimm EA. Negative association of melanoma differentiation-associated gene (mda-7) and inducible nitric oxide synthase (iNOS) in human melanoma: MDA-7 regulates iNOS expression in melanoma cells. Mol Cancer Ther. 2: 9-17. 2003.

23. Salvucci O, Carsana M, Bersani I, Tragni G, and Anichini A. Antiapoptotic role of endogenous nitric oxide in human melanoma cells. Cancer Res. 61: 318-326. 2001.

24. Fecker LF, Eberle J, Orfanos CE, and Geilen CC. Inducible nitric oxide synthase is expressed in normal human melanocytes but not in melanoma cells in response to tumor necrosis factor- $\alpha$, interferon- $\gamma$, and lipopolysaccharide. J Invest Dermatol. 118: 1019-1025. 2002.

25. Ross D, Cotgreave I, and Moldeus P. The interaction of reduced glutathione with active oxygen species generated by xanthine-oxidase-catalyzed metabolism of xanthine. Biochim Biophys Acta. 841: 278-282. 1985.

26. Troll $\mathrm{W}$ and Wiesner $\mathrm{R}$. The role of oxygen radicals as a possible mechanism of tumor promotion. Annu Rev Pharmacol Toxicol. 25: 509-528. 1985.

27. Ahmed B and Van Den Oord JJ. Expression of the inducible isoform of nitric oxide synthase in pigment cell lesions of the skin. Br J Dermatol. 142: 432-440. 2000.

28. Ekmekcioglu S, Ellerhorst J, Smid CM, Prieto VG, Munsell M, Buzaid AC, and Grimm EA. Inducible nitric oxide synthase and nitrotyrosine in human metastatic melanoma tumors correlate with poor survival. Clin Cancer Res. 6: 4768-4775. 2000.

29. Tschugguel W, Pustelnik T, Lass H, Mildner M, Weninger W, Schneeberger C, Jansen B, Tschachler E, Waldhor T, Huber JC, and Pehamberger H. Inducible nitric oxide synthase (iNOS) expression may predict distant metastasis in human melanoma. Br J Cancer. 79: 1609-1612. 1999.

30. Narayanan BA, Narayanan NK, Simi B, and Reddy BR. Modulation of inducible nitric oxide synthase and related proinflammatory genes by the omega-3 fatty acid docosahexaenoic acid in human colon cancer cells. Cancer Res. 63: 972-979. 2003.

31. Takahashi M, Fukuda K, Ohata T, Sugimura T, and Wakabayashi K. Increased expression of inducible and endothelial constitutive nitric oxide synthases in rat colon tumors induced by azoxymethane. Cancer Res. 57: 12331237. 1997.

32. Ambs S, Merriam WG, Bennett WP, Felley-Bosco E, Ogunfusika MO, Oser SM, Klein S, Shields PG, Billiar TR, and Harris CC. Frequent nitric oxide synthase-2 expression in human colon adenomas: Implication for tumor angiogenesis and colon cancer progression. Cancer Res. 58: 334-341. 1998.

33. Reddy BS, Hirose Y, Cohen LA, Simi B, Cooma I, and Rao CV. Preventive potential of wheat bran fractions against experimental colon carcinogenesis: Implications for human colon cancer prevention. Cancer Res. 60: 4792-4797. 2000.

34. Narayanan BA, Narayanan NK, Desai D, Pittman B, and Reddy BS. Effects of a combination of docosahexaenoic acid and 1,4-phenylene bis(methylene) selenocyanate on cyclooxygenase 2 , inducible nitric oxide synthase and betacatenin pathways in colon cancer cells. Carcinogenesis. 25: 2443-2449. 2004.

35. Williams JL, Nath N, Chen J, Hundley TR, Gao J, Kopelovich L, Kashfi K, and Rigas B. Growth inhibition of human colon cancer cells by nitric oxide (NO)-donating aspirin is associated with cyclooxygenase- 2 induction and $\beta$-catenin/T-cell factor signaling, nuclear factor- $\kappa \mathrm{B}$, and NO synthase 2 inhibition: Implications for chemoprevention. Cancer Res. 63: 7613-7618. 2003.

36. Hirose Y, Rao CV, and Reddy BS. Modulation of inducible nitric oxide synthase expression in rat intestinal cells by colon tumor promoters. Int J Oncol. 18: 141-146. 2001.

37. Rao CV, Indranie C, Simi B, Manning PT, Connor JR, and Reddy BS. Chemopreventive properties of a selective inducible nitric oxide synthase inhibitor in colon carcinogenesis, administered alone or in combination with celecoxib, a selective cyclooxygenase- 2 inhibitor. Cancer Res. 62: 165-170. 2002.

38. Takahashi T, Takasuka N, Iigo M, Baba M, Nishino H, Tsuda H, and Okuyama T. Isoliquiritigenin, a flavonoid from licorice, reduces prostaglandin E2 and nitric oxide, causes apoptosis, and suppresses aberrant crypt foci development. Cancer Sci. 95: 448-453. 2004.

39. Reddy BS. Studies with the azoxymethane-rat preclinical model for assessing colon tumor development and chemoprevention. Environ Mol Mutagen. 44: 26-35. 2004.

40. Watanabe K, Kawamori T, Nakatsugi S, and Wakabayashi K. COX-2 and iNOS, good targets for chemoprevention of colon cancer. Biofactors. 12: 129-133. 2000.

41. Liu Y, Borchert GL, and Phang JM. Polyoma enhancer activator 3 , an ets transcription factor, mediates the induction of cyclooxygenase-2 by nitric oxide in colorectal cancer cells. J Biol Chem. 279: 18694-18700. 2004.

42. Goto T, Haruma K, Kitadai Y, Ito M, Yoshihara M, Sumii K, Hayakawa N, and Kajiyama G. Enhanced expression of inducible nitric oxide synthase and nitrotyrosine in gastric mucosa of gastric cancer patients. Clin Cancer Res. 5: 1411-1415. 1999.

43. Son HJ, Rhee JC, Park DI, Kim YH, Rhee PL, Koh KC, Paik SW, Choi KW, and Kim JJ. Inducible nitric oxide synthase expression in gastroduodenal diseases infected with Helicobacter pylori. Helicobacter. 6: 37-43. 2001.

44. Doi C, Noguchi Y, Marat D, Saito A, Fukuzawa K, Yoshikawa T, Tsuburaya A, and Ito T. Expression of nitric oxide synthase in gastric cancer. Cancer Lett. 144: 161-167. 
1999.

45. Son HJ, Kim YH, Park DI, Kim JJ, Rhee PL, Paik SW, Choi $\mathrm{KW}$, Song SY, and Rhee JC. Interaction between cyclooxygenase- 2 and inducible nitric oxide synthase in gastric cancer. J Clin Gastroenterol. 33: 383-388. 2001.

46. Wang YZ, Cao YQ, Wu JN, Chen M, Cha XY. Expression of nitric oxide synthase in human gastric carcinoma and its relation to p53, PCNA. World J Gastroenterol. 11: 46-50. 2005.

47. Varanasi RV, Fantry GT, and Wilson KT. Decreased prevalence of Helicobacter pylori infection in gastroesophageal reflux disease. Helicobacter. 3: 188-194; 1998.

48. Shen J, Wang R, Wang L, Wang Z, Xing H, Wang B, Li M, Hua Z, Wang J, Guo C, Wang X, and Xu X. Study on the relationship between susceptibility of stomach neoplasm cancer and polymorphism of inducible nitric oxide synthase gene. Zhonghua Liu Xing Bing Xue Za Zhi. 23: 374-377. 2002.

49. Tatemichi M, Sawa T, Gilibert I, Tazawa H, Katoh T, and Ohshima H. Increased risk of intestinal type of gastric adenocarcinoma in Japanese women associated with long forms of CCTTT pentanucleotide repeat in the inducible nitric oxide synthase promoter. Cancer Lett. 217: 197-202. 2005.

50. Shen J, Wang RT, Wang LW, Xu YC, and Wang XR. A novel genetic polymorphism of inducible nitric oxide synthase is associated with an increased risk of gastric cancer. World J Gastroenterol. 10: 3278-3283. 2004.

51. Touati E, Michel V, Thiberge JM, Wuscher N, Huerre M, and Labigne A. Chronic Helicobacter pylori infections induce gastric mutations in mice. Gastroenterology. 124: 1408-1419. 2003.

52. Rieder G, Hofmann JA, Hatz RA, Stolte M, and Enders GA. Up-regulation of inducible nitric oxide synthase in Helicobacter pylori-associated gastritis may represent an increased risk factor to develop gastric carcinoma of the intestinal type. Int J Med Microbiol. 293: 403-412. 2003.

53. Hahm KB, Lee KJ, Kim JH, Cho SW, and Chung MH. Helicobacter pylori infection, oxidative DNA damage, gastric carcinogenesis, and reversibility by rebamipide. Dig Dis Sci. 43: 72S-77S. 1998.

54. Chang CS, Chen WN, Lin HH, Wu CC, and Wang CJ. Increased oxidative DNA damage, inducible nitric oxide synthase, nuclear factor $\kappa \mathrm{B}$ expression and enhanced antiapoptosis-related proteins in Helicobacter pyloriinfected non-cardiac gastric adenocarcinoma. World J Gastroenterol. 10: 2232-2240. 2004.

55. Hahm KB, Lee KJ, Choi SY, Kim JH, Cho SW, Yim H, Park SJ, and Chung MH. Possibility of chemoprevention by the eradication of Helicobacter pylori: Oxidative DNA damage and apoptosis in H. pylori infection. Am J Gastroenterol. 92: 1853-1857. 1997.

56. Nam KT, Oh SY, Ahn B, Kim YB, Jang DD, Yang KH, Hahm KB, and Kim DY. Decreased Helicobacter pylori associated gastric carcinogenesis in mice lacking inducible nitric oxide synthase. Gut. 53: 1250-1255. 2004.

57. Tanaka H, Kijima H, Tokunaga T, Tajima T, Himeno S, Kenmochi T, Oshiba G, Kise Y, Nishi T, Chino O, Shimada H, Machimura T, Tanaka M, and Makuuchi H. Frequent expression of inducible nitric oxide synthase in esophageal squamous cell carcinomas. Int J Oncol. 14: 1069-1073.
1999.

58. Wilson KT, Fu S, Ramanujam KS, and Meltzer SJ. Increased expression of inducible nitric oxide synthase and cyclooxygenase-2 in Barrett's esophagus and associated adenocarcinomas. Cancer Res. 58: 2929-2934. 1998.

59. Matsumoto M, Furihata M, Kurabayashi A, Araki K, Sasaguri S, and Ohtsuki Y. Association between inducible nitric oxide synthase expression and p53 status in human esophageal squamous cell carcinoma. Oncology. 64: 90-96. 2003.

60. Stoner GD, and Gupta A. Etiology and chemoprevention of esophageal squamous cell carcinoma. Carcinogenesis. 22: 1737-1746. 2001.

61. Chen X, and Yang CS. Esophageal adenocarcinoma: A review and perspectives on the mechanism of carcinogenesis and chemoprevention. Carcinogenesis. 22: 1119-1129. 2001.

62. Wilson KT. Angiogenic markers, neovascularization and malignant deformation of Barrett's esophagus. Dis Esophagus. 15: 16-21. 2002.

63. Chen $\mathrm{T}$ and Stoner GD. Inducible nitric oxide synthase expression in N-nitrosomethylbenzylamine (NMBA)induced rat esophageal tumorigenesis. Mol Carcinog. 40: 232-240. 2004.

64. Chen X, Li N, Wang S, Hong J, Fang M, Yousselfson J, Yang P, Newman RA, Lubet RA, and Yang CS. Aberrant arachidonic acid metabolism in esophageal adenocarcinogenesis, and the effects of sulindac, nordihydroguaiaretic acid, and $\alpha$-difluoromethylornithine on tumorigenesis in a rat surgical model. Carcinogenesis. 23: 2095-2102. 2002.

65. Chen T, Nines RG, Peschke SM, Kresty LA, and Stoner GD. Chemopreventive effects of a selective nitric oxide synthase inhibitor on carcinogen-induced rat esophageal tumorigenesis. Cancer Res. 64: 3714-3717. 2004.

66. Hotz HG, Hines OJ, Foitzik T, and Reber HA. Animal models of exocrine pancreatic cancer. Int J Colorectal Dis. 15: 136-143. 2000.

67. Vickers SM, MacMillan-Crow LA, Green M, Ellis C, and Thompson JA. Association of increased immunostaining for inducible nitric oxide synthase and nitrotyrosine with fibroblast growth factor transformation in pancreatic cancer. Arch Surg. 134: 245-251. 1999.

68. Franco L, Doria D, Bertazzoni E, Benini A, and Bassi C. Increased expression of inducible nitric oxide synthase and cyclooxygenase- 2 in pancreatic cancer. Prostaglandins Other Lipid Mediat. 73: 51-58. 2004.

69. Kong G, Kim EK, Kim WS, Lee YW, Lee JK, Paik SW, Rhee JC, Choi KW, and Lee KT. Inducible nitric oxide synthase (iNOS) immunoreactivity and its relationship to cell proliferation, apoptosis, angiogenesis, clinicopathologic characteristics, and patient survival in pancreatic cancer. Int J Pancreatol. 29: 133-140. 2001.

70. Kong G, Kim EK, Kim WS, Lee KT, Lee YW, Lee JK, Paik $\mathrm{SW}$, and Rhee JC. Role of cyclooxygenase-2 and inducible nitric oxide synthase in pancreatic cancer. J Gastroenterol Hepatol. 17: 914-921. 2002.

71. Kasper HU, Wolf H, Drebber U, Wolf HK, and Kern MA. Expression of inducible nitric oxide synthase and cyclooxygenase- 2 in pancreatic adenocarcinoma: Correlation with microvessel density. World J Gastroenterol. 10: 1918-1922. 2004. 
72. Muerkoster S, Wegehenkel K, Arlt A, Witt M, Sipos B Kruse ML, Sebens T, Kloppel G, Kalthoff H, Folsch UR, and Schafer H. Tumor stroma interactions induce chemoresistance in pancreatic ductal carcinoma cells involving increased secretion and paracrine effects of nitric oxide and interleukin-1 $\beta$. Cancer Res. 64: 1331-1337. 2004.

73. Kisley LR, Barrett BS, Bauer AK, Dwyer-Nield LD, Barthel B, Meyer AM, Thompson DC, and Malkinson AM. Genetic ablation of inducible nitric oxide synthase decreases mouse lung tumorigenesis. Cancer Res. 62: 6850-6856. 2002.

74. Jadeski LC and Lala PK. Nitric oxide synthase inhibition by $\mathrm{N}(\mathrm{G})$-nitro-L-arginine methyl ester inhibits tumor-induced angiogenesis in mammary tumors. Am J Pathol. 155: 13811390. 1999.

75. Jadeski LC, Hum KO, Chakraborty C, and Lala PK. Nitric oxide promotes murine mammary tumour growth and metastasis by stimulating tumour cell migration, invasiveness and angiogenesis. Int J Cancer. 86: 30-39. 2000.

76. Jadeski LC, Chakraborty C, and Lala PK. Nitric oxidemediated promotion of mammary tumour cell migration requires sequential activation of nitric oxide synthase, guanylate cyclase and mitogen-activated protein kinase. Int J Cancer. 106: 496-504. 2003.

77. Ellies LG, Fishman M, Hardison J, Kleeman J, Maglione JE, Manner CK, Cardiff RD, and MacLeod CL. Mammary tumor latency is increased in mice lacking the inducible nitric oxide synthase. Int J Cancer. 106: 1-7. 2003.

78. Rao CV, Cooma I, Rodriguez JG, Simi B, El Bayoumy K, and Reddy BS. Chemoprevention of familial adenomatous polyposis development in the APC(min) mouse model by 1,4-phenylene bis(methylene)selenocyanate. Carcinogenesis. 21: 617-621. 2000.

79. Ahn B and Ohshima H. Suppression of intestinal polyposis in $\mathrm{Apc}^{\mathrm{Min} /+}$ mice by inhibiting nitric oxide production. Cancer Res. 61: 8357-8360. 2001.

80. Zheng X, Rivabene R, Cavallari C, Napolitano M, Avella M, Bravo E, and Botham KM. The effects of chylomicron remnants enriched in n-3 or n-6 polyunsaturated fatty acids on the transcription of genes regulating their uptake and metabolism by the liver: influence of cellular oxidative stress. Free Radic Biol Med. 32: 1123-1131. 2002.

81. Fornai F, Lenzi P, Gesi M, Ferrucci M, Lazzeri G, Capobianco L, De Blasi A, Battaglia G, Nicoletti F, Ruggieri S, and Paparelli A. Similarities between methamphetamine toxicity and proteasome inhibition. Ann NY Acad Sci. 1025: 162-170. 2004.

82. Calvisi DF, Ladu S, Hironaka K, Factor VM, and Thorgeirsson SS. Vitamin E down-modulates iNOS and NADPH oxidase in c-Myc/TGF-alpha transgenic mouse model of liver cancer. J Hepatol. 41: 815-822. 2004.

83. Kotake Y, Kishida H, Nakae D, and Floyd RA. Nitric oxide production by primary liver cells isolated from amino acid diet fed rats. Methods Enzymol. 396: 535-541. 2005.

84. Floyd RA, Kotake Y, Hensley K, Nakae D, and Konishi Y. Reactive oxygen species in choline deficiency induced carcinogenesis and nitrone inhibition. Mol Cell Biochem. 234/235: 195-203. 2002.

85. Nakae D, Kishida H, Enami T, Konishi Y, Hensley KL, Floyd RA, and Kotake Y. Effects of phenyl N-tert-butyl nitrone and its derivatives on the early phase of hepatocarcinogenesis in rats fed a choline-deficient, L- amino acid-defined diet. Cancer Sci. 94: 26-31. 2003.

86. Mattano SS, Palella TD, and Mitchell BS. Mutations induced at the hypoxanthine-guanine phosphoribosyltransferase locus of human T-lymphoblasts by perturbations of purine deoxyribonucleoside triphosphate pools. Cancer Res. 50: 4566-4571. 1990.

87. Nakae D, Uematsu F, Kishida H, Kusuoka O, Katsuda S, Yoshida M, Takahashi M, Maekawa A, Denda A, Konishi Y, Kotake Y, and Floyd RA. Inhibition of the development of hepatocellular carcinomas by phenyl N-tert-butyl nitrone in rats fed with a choline-deficient, L-amino acid-defined diet. Cancer Lett. 206: 1-13. 2004.

88. Floyd RA. Nitrones as therapeutics in age-related diseases. Aging Cell. 5: 51-57. 2006.

89. Vaananen AJ, Kankuri E, and Rauhala P. Nitric oxiderelated species-induced protein oxidation: reversible, irreversible, and protective effects on enzyme function of papain. Free Radic Biol Med. 38: 1102-1111. 2005.

90. Afshar RK, Patra AK, and Mascharak PK. Light-induced inhibition of papain by a $\{\mathrm{Mn}-\mathrm{NO}\} 6$ nitrosyl: Identification of papain-SNO adduct by mass spectrometry. J Inorg Biochem. 99: 1458-1464. 2005.

91. Xian M, Chen X, Liu Z, Wang K, and Wang PG. Inhibition of papain by S-nitrosothiols. Formation of mixed disulfides. J Biol Chem. 275: 20467-20473. 2000.

92. Meara JP and Rich DH. Mechanistic studies on the inactivation of papain by epoxysuccinyl inhibitors. J Med Chem. 39: 3357-3366. 1996.

93. Li J, Billiar TR, Talanian RV, and Kim YM. Nitric oxide reversibly inhibits seven members of the caspase family via S-nitrosylation. Biochem Biophys Res Commun. 240: 419424. 1997.

94. Leiper J, Murray-Rust J, McDonald N, and Vallance P. Snitrosylation of dimethylarginine dimethylaminohydrolase regulates enzyme activity: further interactions between nitric oxide synthase and dimethylarginine dimethylaminohydrolase. Proc Natl Acad Sci USA. 99: 13527-13532. 2002.

95. Leiper JM, and Vallance P. The synthesis and metabolism of asymmetric dimethylarginine (ADMA). Eur J Clin Pharmacol. 62 Suppl 1: 33-38. 2006.

96. Murray-Rust J, Leiper J, McAlister M, Phelan J, Tilley S, Santa MJ, Vallance P, and McDonald N. Structural insights into the hydrolysis of cellular nitric oxide synthase inhibitors by dimethylarginine dimethylaminohydrolase. Nat Struct Biol. 8: 679-683. 2001.

97. Stamler JS, Toone EJ, Lipton SA, and Sucher NJ. (S)NO signals: translocation, regulation, and a consensus motif. Neuron. 18: 691-696. 1997.

98. Hess DT, Matsumoto A, Nudelman R, and Stamler JS. Snitrosylation: spectrum and specificity. Nature Cell Biology. 3: E46-E49. 2001.

99. Gao C, Guo H, Wei J, Mi Z, Wai PY, and Kuo PC. Identification of S-nitrosylated proteins in endotoxinstimulated RAW264.7 murine macrophages. Nitric Oxide. 12: 121-126. 2005.

100. Kuncewicz T, Sheta EA, Goldknopf IL, and Kone BC. Proteomic analysis of S-nitrosylated proteins in mesangial cells. Mol Cell Proteomics. 2: 156-163. 2003.

101. Martinez-Ruiz A and Lamas S. Detection and proteomic identification of S-nitrosylated proteins in endothelial cells. Arch Biochem Biophys. 423: 192-199. 2004. 
102. Barrett DM, Black SM, Todor H, Schmidt-Ullrich RK, Dawson KS, and Mikkelsen RB. Inhibition of proteintyrosine phosphatases by mild oxidative stresses is dependent on S-nitrosylation. J Biol Chem. 280: 1445314461. 2005.

103. Nedospasov A, Rafikov R, Beda N, and Nudler E. An autocatalytic mechanism of protein nitrosylation. Proc Natl Acad Sci USA. 97: 13543-13548. 2000.

104. Takakura K, Beckman JS, MacMillian-Crow LA, and Crow JP. Rapid and irreversible inactivation of protein tyrosine phosphatases PTP1B, CD45, and LAR by peroxynitrite. Arch Biochem Biophys. 369: 197-207. 1999.

105. Callsen D, Sandau KB, and Brune B. Nitric oxide and superoxide inhibit platelet-derived growth factor receptor phosphotyrosine phosphatases. Free Radic Biol Med. 26: 1544-1553. 1999.

106. Li S and Whorton AR. Regulation of Protein tyrosine phosphatase 1B in intact cells by S-nitrosothiols. Arch Biochem Biophys. 410: 269-270. 2003.

107. Salsman SJ, Hensley K, and Floyd RA. Sensitivity of protein tyrosine phosphatase activity to the redox environment, cytochrome $\mathrm{C}$, and microperoxidase. Antioxid Redox Signal. 7: 1078-1088. 2005.

108. Gaston BM, Carver J, Doctor A, and Palmer LA. Snitrosylation signaling in cell biology. Mol Interv. 3: 253263. 2003.

109. Jensen DE, Belka GK, and Du Bois GC. SNitrosoglutathione is a substrate for rat alcohol dehydrogenase class III isoenzyme. Biochem J. 331 (Pt 2): 659-668. 1998.

110. Liu L, Hausladen A, Zeng M, Que L, Heitman J, and Stamler JS. A metabolic enzyme for S-nitrosothiol conserved from bacteria to humans. Nature. 410: 490-494. 2001.

111. Jourd'heuil D, Laroux FS, Miles AM, Wink DA, and Grisham MB. Effect of superoxide dismutase on the stability of S-nitrosothiols. Arch Biochem Biophys. 361: 323-330. 1999.

112. Nikitovic D and Holmgren A. S-nitrosoglutathione is cleaved by the thioredoxin system with liberation of glutathione and redox regulating nitric oxide. J Biol Chem. 271: 19180-19185. 1996.

113. Trujillo M, Alvarez MN, Peluffo G, Freeman BA, and Radi R. Xanthine oxidase-mediated decomposition of Snitrosothiols. J Biol Chem. 273: 7828-7834. 1998.

114. Yamamoto M, Yang G, Hong C, Liu J, Holle E, Yu X, Wagner T, Vatner SF, and Sadoshima J. Inhibition of endogenous thioredoxin in the heart increases oxidative stress and cardiac hypertrophy. J Clin Invest. 112: 13951406. 2003.

115. Yu CX, Li S, and Whorton AR. Redox regulation of PTEN by S-nitrosothiols. Mol Pharmacol. 68: 847-854. 2005.

116. Azad N, Vallyathan V, Wang L, Tantishaiyakul V, Stehlik C, Leonard SS, and Rojanasakul Y. S-nitrosylation of Bcl-2 inhibits its ubiquitin-proteasomal degradation. A novel antiapoptotic mechanism that suppresses apoptosis. J Biol Chem. 281: 34124-34134. 2006.

117. Kim JE and Tannenbaum SR. S-Nitrosation regulates the activation of endogenous procaspase-9 in HT-29 human colon carcinoma cells. J Biol Chem. 279: 9758-9764. 2004.

118. Torok NJ, Higuchi H, Bronk S, and Gores GJ. Nitric oxide inhibits apoptosis downstream of cytochrome c release by nitrosylating caspase 9. Cancer Res. 62: 1648-1653. 2002.

119. Radisavljevic Z. Nitric oxide suppression triggers apoptosis through the FKHRL1 (FOXO3A)/ROCK kinase pathway in human breast carcinoma cells. Cancer. 97: 1358-1363. 2003.

120. Jaffrey SR and Snyder SH. The biotin switch method for the detection of S-nitrosylated proteins. Sci STKE. 2001: L1. 2001.

121. Laguinge LM, Lin S, Samara RN, Salesiotis AN, and Jessup JM. Nitrosative stress in rotated three-dimensional colorectal carcinoma cell cultures induces microtubule depolymerization and apoptosis. Cancer Res. 64: $2643-$ 2648. 2004.

122. Kampa M, Hatzoglou A, Notas G, Niniraki M, Kouroumalis E, and Castanas E. Opioids are non-competitive inhibitors of nitric oxide synthase in T47D human breast cancer cells. Cell Death Differ. 8: 943-952. 2001.

123. Caso G, McNurlan MA, McMillan ND, Eremin O, and Garlick PJ. Tumour cell growth in culture: Dependence on arginine. Clin Sci. 107: 371-379. 2004.

124. Thomsen LL and Miles DW. Role of nitric oxide in tumour progression: Lessons from human tumours. Cancer Metastasis Rev. 17: 107-118. 1998.

125. Vakkala M, Kahlos K, Lakari E, Paakko P, Kinnula V, and Soini Y. Inducible nitric oxide synthase expression, apoptosis, and angiogenesis in in situ and invasive breast carcinomas. Clin Cancer Res. 6: 2408-2416. 2000.

126. Bing RJ, Miyataka M, Rich KA, Hanson N, Wang X, Slosser HD, and Shi SR. Nitric oxide, prostanoids, cyclooxygenase, and angiogenesis in colon and breast cancer. Clin Cancer Res. 7: 3385-3392. 2001.

127. De Paepe B, Verstraeten VM, De Potter CR, and Bullock GR. Increased angiotensin II type-2 receptor density in hyperplasia, DCIS and invasive carcinoma of the breast is paralleled with increased iNOS expression. Histochem Cell Biol. 117: 13-19. 2002.

128. Cardone MH, Roy N, Stennicke HR, Salvesen GS, Franke TF, Stanbridge E, Frisch S, and Reed JC. Regulation of cell death protease caspase- 9 by phosphorylation. Science. 282. 1318-1321. 1998.

129. Dahia PL, Aguiar RC, Alberta J, Kum JB, Caron S, Sill H, Marsh DJ, Ritz J, Freedman A, Stiles C, and Eng C. PTEN is inversely correlated with the cell survival factor Akt/PKB and is inactivated via multiple mechanismsin haematological malignancies. Hum Mol Genet. 8: 185-193. 1999.

130. Datta SR, Dudek H, Tao X, Masters S, Fu H, Gotoh Y, and Greenberg ME. Akt phosphorylation of BAD couples survival signals to the cell-intrinsic death machinery. Cell. 91: 231-241. 1997.

131. del Peso L, Gonzalez-Garcia M, Page C, Herrera R, and Nunez G. Interleukin-3-induced phosphorylation of BAD through the protein kinase Akt. Science. 278: 687-689. 1997.

132. Has-Kogan D, Shalev N, Wong M, Mills G, Yount G, and Stokoe D. Protein kinase B (PKB/Akt) activity is elevated in glioblastoma cells due to mutation of the tumor suppressor PTEN/MMAC. Curr Biol. 8: 1195-1198. 1998.

133. Kandel ES and Hay N. The regulation and activities of the multifunctional serine/threonine kinase Akt/PKB. Exp Cell Res. 253: 210-229. 1999.

134. Stambolic V, Suzuki A, Lois de la Pompa J, Brothers GM, 
Mirtsos C, Sasaki T, Ruland J, Penninger JM, Siderovski DP, and Mak TW. Negative regulation of PKB/Aktdependent cell survival by the tumor suppressor PTEN. Cell. 95: 29-39. 1998.

135. Wu X, Senechal K, Neshat MS, Whang YE, and Sawyers CL. The PTEN/MMAC1 tumor suppressor phosphatase functions as a negative regulator of the phosphoinositide 3kinase/Akt pathway. Proc Natl Acad Sci USA. 95: 1558715591. 1998.

136. Leslie NR, Bennett D, Lindsay YE, Stewart H, Gray A, and Downes CP. Redox regulation of PI 3-kinase signalling via inactivation of PTEN. EMBO J. 22: 5501-5510. 2003.

137. Leslie NR and Downes CP. PTEN: The down side of PI 3kinase signalling. Cell Signal. 14: 285-295. 2002.

138. Li J, Yen C, Liaw D, Podsypanina K, Bose S, Wang SI, Puc J, Miliaresis C, Rodgers L, McCombie R, Bigner SH, Giovanella BC, Ittmann M, Tycko B, Hibshoosh H, Wigler $\mathrm{MH}$, and Parsons R. PTEN, a putative protein tyrosine phosphatase gene mutated in human brain, breast, and prostate cancer. Science. 275: 1943-1947. 1997.

139. Maehama T and Dixon JE. PTEN: A tumour suppressor that functions as a phospholipid phosphatase. Trends Cell Biol. 9: 125-128. 1999.

140. Myers MP and Tonks NK. PTEN: Sometimes taking it off can be better than putting it on. Am J Hum Genet. 61: 12341238. 1997.

141. Steck PA, Pershouse MA, Jasser SA, Yung WKA, Lin H, Ligon AH, Langford LA, Baumgard ML, Hattier T, Davis T, Frye C, Hu R, Bradley S, Teng DHF, and Tavtigian SV. Identification of a candidate tumour suppressor gene, MMAC1, at chromosome 10q23.3 that is mutated in multiple advanced cancers. Nature Genetics. 15: 356-362. 1997.

142. Savitsky PA and Finkel T. Redox regulation of Cdc25C. J Biol Chem. 277: 20535-20540. 2002.

143. Genaro AM, Hortelano S, Alvarez A, Martinez C, and Bosca L. Splenic B lymphocyte programmed cell death is prevented by nitric oxide release through mechanisms involving sustained Bcl-2 levels. J Clin Invest. 95: 18841890. 1995.

144. Atik E, Ergin M, Erdogan S, and Tuncer I. Inducible nitric oxide synthase and apoptosis in human B cell lymphomas. Mol Cell Biochem. 290: 205-209. 2006.

145. Roman V, Billard C, Kern C, Ferry-Dumazet H, Izard JC, Mohammad R, Mossalayi DM, and Kolb JP. Analysis of resveratrol-induced apoptosis in human B-cell chronic leukaemia. Br J Haematol. 117: 842-851. 2002.

146. Billard C, Izard JC, Roman V, Kern C, Mathiot C, Mentz F, and Kolb JP. Comparative antiproliferative and apoptotic effects of resveratrol, epsilon-viniferin and vine-shots derived polyphenols (vineatrols) on chronic B lymphocytic leukemia cells and normal human lymphocytes. Leuk Lymphoma. 43: 1991-2002. 2002.

147. Ferrer P, Asensi M, Priego S, Benlloch M, Mena S, Ortega A, Obrador E, Esteve JM, and Estrela JM. Nitric oxide mediates natural polyphenol-induced Bcl-2 down-regulation and activation of cell death in metastatic B16 melanoma. J Biol Chem. 282: 2880-2890. 2007.

148. Tamir S, Rojas-Walker T, Gal A, Weller AH, Li X, Fox JG, Wogan GN, and Tannenbaum SR. Nitric oxide production in relation to spontaneous B-cell lymphoma and myositis in SJL mice. Cancer Res. 55: 4391-4397. 1995.
149. Corrales FJ, Perez-Mato I, Sanchez del Pino MM, Ruiz F, Castro C, Garcia-Trevijano ER, Latasa U, Martinez-Chantar ML, Martinez-Cruz A, Avila MA, and Mato JM. Regulation of mammalian liver methionine adenosyltransferase. J Nutr. 132: 2377S-2381S. 2002.

150. Mato JM, Corrales FJ, Lu SC, and Avila MA. SAdenosylmethionine: A control switch that regulates liver function. FASEB J. 16: 15-26. 2002.

151. Avila MA, Mingorance J, Martinez-Chantar ML, Casado M, Martin-Sanz P, Bosca L, and Mato JM. Regulation of rat liver S-adenosylmethionine synthetase during septic shock: role of nitric oxide. Hepatology. 25: 391-396. 1997.

152. Ruiz F, Corrales FJ, Miqueo C, and Mato JM. Nitric oxide inactivates rat hepatic methionine adenosyltransferase in vivo by S-nitrosylation. Hepatology. 28: 1051-1057. 1998.

153. Avila MA, Corrales FJ, Ruiz F, Sanchez-Gongora E, Mingorance J, Carretero MV, and Mato IM. Specific interaction of methionine adenosyltransferase with free radicals. Biofactors. 8: 27-32. 1998.

154. Perez-Mato I, Castro C, Ruiz FA, Corrales FJ, and Mato JM. Methionine adenosyltransferase S-nitrosylation is regulated by the basic and acidic amino acids surrounding the target thiol. J Biol Chem. 274: 17075-17079. 1999.

155. Castro C, Ruiz FA, Perez-Mato I, Sanchez del Pino MM, LeGros L, Geller AM, Kotb M, Corrales FJ, and Mato JM. Creation of a functional S-nitrosylation site in vitro by single point mutation. FEBS Lett. 459: 319-322. 1999.

156. Avila MA, Carretero MV, Rodriguez EN, and Mato JM. Regulation by hypoxia of methionine adenosyltransferase activity and gene expression in rat hepatocytes. Gastroenterology. 114: 364-371; 1998.

157. Corrales FJ, Ruiz F, and Mato JM. In vivo regulation by glutathione of methionine adenosyltransferase Snitrosylation in rat liver. J Hepatol. 31: 887-894. 1999.

158. Lu SC Alvarez L, Huang ZZ, Chen L, An W, Corrales FJ, Avila MA, Kanel G, and Mato JM. Methionine adenosyltransferase 1A knockout mice are predisposed to liver injury and exhibit increased expression of genes involved in proliferation. Proc Natl Acad Sci USA. 98: 5560-5565. 2001.

159. Chen L, Zeng Y, Yang H, Lee TD, French SW, Corrales FJ, Garcia-Trevijano ER, Avila MA, Mato JM, and Lu SC. Impaired liver regeneration in mice lacking methionine adenosyltransferase 1A. FASEB J. 18: 914-916. 2004.

160. Martinez-Chantar ML, Corrales FJ, Martinez-Cruz LA, Garcia-Trevijano ER, Huang ZZ, Chen L, Kanel G, Avila MA, Mato JM, and Lu SC. Spontaneous oxidative stress and liver tumors in mice lacking methionine adenosyltransferase 1A. FASEB J. 16: 1292-1294. 2002.

161. Garcia-Trevijano ER, Martinez-Chantar ML, Latasa MU, Mato JM, and Avila MA. NO sensitizes rat hepatocytes to proliferation by modifying S-adenosylmethionine levels. Gastroenterology. 122: 1355-1363. 2002.

162. Martinez-Chantar ML, Garcia-Trevijano ER, Latasa MU, Perez-Mato I, Sanchez del Pino MM, Corrales FJ, Avila $\mathrm{MA}$, and Mato JM. Importance of a deficiency in Sadenosyl-L-methionine synthesis in the pathogenesis of liver injury. Am J Clin Nutr. 76: 1177S-1182S. 2002.

163. Price JA, Kovach SJ, Johnson T, Koniaris LG, Cahill PA, Sitzmann JV, and McKillop IH. Insulin-like growth factor I is a comitogen for hepatocyte growth factor in a rat model of hepatocellular carcinoma. Hepatology. 36: 1089-1097. 
2002.

164. Paneda C, Gorospe I, Herrera B, Nakamura T, Fabregat I, and Varela-Nieto I. Liver cell proliferation requires methionine adenosyltransferase 2A mRNA up-regulation. Hepatology. 35: 1381-1391. 2002.

165. Newberne PM. Lipotropic factors and oncogenesis. Adv Exp Med Biol. 206: 223-251. 1986.

166. Cabrero C, Duce AM, Ortiz P, Alemany S, Mato JM. Specific loss of the high-molecular-weight form of Sadenosyl-L-methionine synthetase in human liver cirrhosis. Hepatology. 8: 1530-1534. 1988.

167. McNaughton L, Puttagunta L, Martinez-Cuesta MA, Kneteman N, Mayers I, Moqbel R, Hamid Q, and Radomski MW. Distribution of nitric oxide synthase in normal and cirrhotic human liver. Proc Natl Acad Sci USA. 99: 1716117166. 2002.

168. Mohammed NA, Abd El-Aleem S, Appleton I, Maklouf MM, Said M, and McMahon RF. Expression of nitric oxide synthase isoforms in human liver cirrhosis. J Pathol. 200: 647-655. 2003.

169. Pavanato A, Tunon MJ, Sanchez-Campos S, Marroni CA, Llesuy S, Gonzalez-Gallego J, and Marroni N. Effects of quercetin on liver damage in rats with carbon tetrachlorideinduced cirrhosis. Dig Dis Sci. 48: 824-829. 2003.

170. Wei CL, Hon WM, Lee KH, and Khoo HE. Temporal expression of hepatic inducible nitric oxide synthase in liver cirrhosis. World J Gastroenterol. 11: 362-367. 2005.

171. McCormick F. The ras pathway in cancer (abstract). Am Assoc Cancer Res. Abstract Number SY23-01. 2006.

172. Sridhar SS, Hedley D, and Siu LL. Raf kinase as a target for anticancer therapeutics. Mol Cancer Ther. 4: 677-685. 2005.

173. Rowinsky EK, Windle JJ, and Von Hoff DD. Ras protein farnesyltransferase: A strategic target for anticancer therapeutic development. J Clin Oncol. 17: 3631-3652. 1999.

174. Lander HM, Ogiste JS, Pearce SFA, Levi R, and Novogrodsky A. Nitric oxide-stimulated guanine nucleotide exchange on p21 ${ }^{\text {ras }}$. J Biol Chem. 270: 7017-7020. 1995.

175. Lander HM, Ogiste JS, Teng KK, and Novogrodsky A. p2 $1^{\text {ras }}$ as a common signaling target of reactive free radicals and cellular redox stress. J Biol Chem. 270: 21195-21198. 1995.

176. Mirza UA, Chait BT, and Lander HM. Monitoring reactions of nitric oxide with peptides and proteins by electrospray ionization-mass spectrometry. J Biol Chem. 270: 1718517188. 1995.

177. Lander HM, Hajjar DP, Hempstead BL, Mirza UA, Chait
BT, Campbell S, and Quilliam LA. A molecular redox switch on p21 ${ }^{\text {ras }}$. J Biol Chem. 272: 4323-4326. 1997.

178. Deora AA, Win T, Vanhaesebroeck B, and Lander HM. A redox-triggered ras-effector interaction. Recruitment of phosphatidylinositol 3'-kinase to Ras by redox stress. J Biol Chem. 273: 29923-29928. 1998.

179. Heo $J$ and Campbell SL. Mechanism of $p 21^{\text {Ras }}$ Snitrosylation and kinetics of nitric oxide-mediated guanine nucleotide exchange. Biochem. 43: 2314-2322. 2004.

180. Deora AA, Hajjar DP, and Lander HM. Recruitment and activation of Raf-1 kinase by nitric oxide-activated Ras. Biochem. 39: 9901-9908. 2000.

181. Oliveira CJ, Schindler F, Ventura AM, Morais MS, Arai RJ, Debbas V, Stern A, and Monteiro HP. Nitric oxide and cGMP activate the Ras-MAP kinase pathway-stimulating protein tyrosine phosphorylation in rabbit aortic endothelial cells. Free Radic Biol Med. 35: 381-396. 2003.

182. Lander HM, Jacovina AT, Davis RJ, and Tauras JM. Differential activation of mitogen-activated protein kinases by nitric oxide-related species. J Biol Chem. 271: 1970519709. 1996.

183. Teng KK, Esposito DK, Schwartz GD, Lander HM, and Hempstead BL. Activation of c-Ha-Ras by nitric oxide modulates survival responsiveness in neuronal PC12 cells. J Biol Chem. 274: 37315-37320. 1999.

184. Brennan LA, Wedgwood S, Bekker JM, and Black SM. Nitric oxide activates $\mathrm{p} 21^{\text {ras }}$ and leads to the inhibition of endothelial NO synthase by protein nitration. DNA Cell Biol. 22: 317-328. 2003.

185. Kaji T, Kaieda I, Hisatsune T, and Kaminogawa S. 3Morpholinosydnonimine hydrochloride induces p53dependent apoptosis in murine primary neural cells: A critical role for $\mathrm{p} 21^{\text {ras }}$-MAPK-p19ARF pathway. Nitric. Oxide. 6: 125-134. 2002.

186. Stahl S, Ittrich C, Marx-Stoelting P, Kohle C, Altug-Teber O, Riess O, Bonin M, Jobst J, Kaiser S, Buchmann A, and Schwarz M. Genotype-phenotype relationships in hepatocellular tumors from mice and man. Hepatology. 42: 353-361. 2005.

187. Hwang YH, Choi JY, Kim S, Chung ES, Kim T, Koh SS, Lee B, Bae SH, Kim J, and Park YM. Over-expression of craf-1 proto-oncogene in liver cirrhosis and hepatocellular carcinoma. Hepatol Res. 29: 113-121. 2004.

188. He H, Dai F, Yu L, She X, Zhao Y, Jiang J, Chen X, and Zhao S. Identification and characterization of nine novel human small GTPases showing variable expressions in liver cancer tissues. Gene Expr. 10: 231-242. 2002. 